\title{
Eficacia y justicia del orden natural de la equidad
}

\author{
Manuel María Zorrilla Ruiz \\ Catedrático Emérito de la Universidad de Deusto \\ Ex Presidente del Tribunal Superior de Justicia del País Vasco \\ Presidente de la Asociación de Jueces y Magistrados Jubilados de España
}

Recibido: 02.09 .09

Aceptado: 22.10 .09

Resumen: La generalización y el casuismo son modos alternativos de producción del Derecho objetivo. Ambas orientaciones han ganado terreno de acuerdo con la perfección lograda en sus respectivas experiencias de aplicación. Aunque el carácter general del Derecho viene impuesto por su propia seguridad, no se comprende sin la asistencia de las normas del depósito del orden natural. A este panorama pertenecen las varias e importantes cuestiones que a la equidad conciernen. Una interpretación razonable del sistema español lleva a la conclusión de que -además de atenerse a las exigencias concretas de la carta política- las leyes positivas no pueden atentar contra la justicia material y la equidad. Tal es el sentido del esfuerzo de transformación que la legalidad fundamental promueve para alcanzar las soluciones y adelantos demandados por el progreso de los sectores del ordenamiento jurídico, sus aplicaciones jurisdiccionales o los más ventajosos de sus equivalentes o sustitutivos procesales.

Palabras clave: Equidad, orden natural, positivismo legalista, aplicación judicial, particularidades constitucionales.

Abstract: The generalness and the casuistry are the alternative ways of producing law. Both orientations have improved according to the perfection acquired in their respective experiences of application. The general character of the law is imposed by its own security, but it is not understandable without the support of the rules proceeding from the natural law. The several and important questions concerning to the equity, belong to this panorama. A reasonable interpretation of the Spanish constitutional law shows that the positive rules cannot break the material justice and the equity, besides their agreement with the specific contents of the Constitution. This is the meaning of the transformer force which the fundamental legislation promoves to reach the solutions and the advances required by the progress of the different sectors of the law applied by the jurisdiction or its most advantageous equivalents.

Key words: Equity, natural law, positive law, judicial application, constitutional peculiarities.

Sumario: 1. Consideraciones de principio sobre la sucesión de los modelos consistentes en la generalización tradicional de las normas de Derecho objetivo y el moderno tratamiento individualizador de la equidad.-2. Circunstancias y particularidades que acompañan al fenómeno de la recepción y estimulación equitativas.-3. Conexiones que cabe 
apreciar entre la aplicación equitativa del Derecho objetivo y la figura de la legislación de caso único.- - Examen de las claves o señales del crédito alcanzado por el sentimiento de equidad y el hecho de su propagación.-5. Valoración del impacto equitativo en cuanto a la protección y garantía de los derechos subjetivos e intereses legítimos a que sus repercusiones alcanzan.-6. Reflexiones que suscitan el fenómeno de la generalidad de la ley y la probable crisis de su preponderancia.- - 7. Ventajas inherentes a la divulgación del valor de la equidad, como reflejo de la justicia material, y a la puesta en práctica de sus operaciones.-8. Exaltación constitucional del sentimiento equitativo y de las energías determinantes de su efectividad transformadora.- -9. Significado de la ponderación de la equidad en la aplicación de las normas de los sectores del ordenamiento jurídico que necesitan de semejante auxilio.-10. Proceso de apertura al robustecimiento y la expansión de las exigencias de condición equitativa.-11. Particularidades que ofrecen la generalización del Derecho objetivo y el retorno a las posiciones de inspiración equitativa.12. Reiteración cíclica de los episodios históricos en que se localizan las reacciones de llamamiento y restauración de la equidad.-13. ¿Cómo se adviene al sentimiento de equidad y se sientan los fundamentos exigibles para edificar el Derecho justo que emana de su conocimiento y puesta en posesión?-14. Consideraciones sobre el significado y las oportunidades que hoy día ofrece la equidad para mitigar los antagonismos conflictivos y zanjar los enfrentamientos que originan.

\section{Consideraciones de principio sobre la sucesión de los modelos consis- tentes en la 'generalización tradicional de las normas del Derecho objetivo' y el moderno 'tratamiento individualizador de la equidad'}

La línea de fuerza de estas reflexiones no solo resulta de explorar académicamente la disyuntiva entre el acatamiento riguroso de los mandatos y prohibiciones del Derecho Positivo -que conjuga los mínimos de justicia material y los máximos de seguridad jurídica- y el tenaz llamamiento o incesante retorno al depósito de las verdades del orden natural. Este giro mejora las rotulaciones de un Derecho natural cuya espinosa definición imprejuzga, junto con otros temas de menor cuantía, los relativos a sus fuentes de generación, al discernimiento histórico de sus contenidos variables y a la coerción aplicable a los estados de conflicto en que sus intervenciones acontecen. Ocuparse de las funciones del orden natural y asociarlas al juego de los temperamentos de equidad es admitir que los repartos de la justicia material, un bien escaso y expuesto a distribuciones arbitrarias, responden al afán -activamente innato- de la persona humana y a la fisonomía -pasivamente innata- de los intereses confiados a su gestión más encomiable. Desde que la inquietud y/o la perspicacia del legislador reparan en la necesidad de proteger una especie de los intereses generales o entienden haber dado 
con el modo mejor de ampararlos, se aprecian las traslaciones ópticas de los bienes y derechos que, como blancos móviles, mudan de emplazamiento y de apariencia. Ello muestra el reverso de la noción de rigidez o innmovilis$m o$, cuando se agudiza el poder del discurso y, usando de la elasticidad característica de la ductilidad evolutiva, parece cuestionarse incluso el axioma de que cada cosa es igual a sí misma. La evolución comprende el dinamismo de las consignas de flexibilidad que se asimilan clarividentemente, debido a su excelencia, y que, a causa de su fuerza moral, se acatan sin discrepancias ni disculpas. Las direcciones en que los cambios orientan los actos generadores del Derecho objetivo informan de sus expectativas -cuya positividad indica la puesta en la ciudad por un legislador resuelto a reforzar la generalidad, temporal y espacial, de las normas-y de la actividad de los órganos jurisdiccionales que, al aplicarlas, delimitan y hacen cumplir su voluntad. También es cierto que se exponen a rectificaciones graduales.

Se defiende una causa cuyos fines cambiantes, colectivamente aconsejables y socialmente ambicionados se ven satisfechos hasta que la técnica histórico-evolutiva de aplicación de las normas jurídicas -estimulante de su continuidad y eficacia- deja de ser tal y deviene una estéril faena de desgaste. Sucede así, porque se enciende la luz roja de los tropiezos -inesperados y súbitamente aparecidos- que obstan a la normalidad conseguida hasta entonces. Ciertas normas jurídicas subsisten mientras la envergadura de las transformaciones registradas -inherentes a las circunstancias del tiempo y del lugar- no paraliza el ímpetu de sus energías, ni mengua el compromiso de dar a cada uno lo que sus actitudes individuales y colectivas merecen en justicia. Llega un momento en que, ante la imposibilidad o dificultad extraordinaria de servir a esos fines, se clama por más renovación para dejar -con sentido de la responsabilidad- fuera de juego los instrumentos normativos que, agotadas las opciones de actualización, envejecen irreversiblemente. El ordenamiento jurídico los desecha porque carecen del valor vital que, gracias al criterio histórico-evolutivo de interpretación, han poseído hasta que les aqueja un síndrome de rechazo de la modernidad que liquida el rendimiento jurídico y social de su existencia.

Estas dificultades -concernientes al sano entendimiento de las normas jurídicas- se corrigen con técnicas de salvamento cuyas aplicaciones no gozan de una prosperidad indefinida. A medida que las normas jurídicas -cuya obsolescencia se combate y trata de aplazarse- acusan su anquilosis, decrecen las oportunidades de evitar la caída en desgracia de ciertos elementos del Derecho objetivo. Consumido el recurso a las circunstancias del tiempo y del lugar que condicionan el espíritu y la finalidad de las leyes o, al menos, ambientan su voluntad de vigencia, hay que abandonar las operaciones infecundas de los conatos tardíos y/o los ejercicios infructuosos para aplicar evolutivamente un Derecho que, rebelde a dicho tratamiento, ya no da más de sí. Este estado de cosas fibroso o esclerótico requiere una terapia de tránsito a normas de nueva factura que ocupan el lugar de las que se reve- 
lan inútiles para continuar protegiendo los intereses legítimos a cuyo servicio se encontraban. Tales cuestiones quedan a cargo de una sutil Ciencia de la Legislación o Política Legislativa que verifica el estancamiento de estas situaciones y la constitución en mora que acarrean. Los legisladores intuyen y, entre líneas, predicen el hecho material de la abolición -modo atípico que, además de la derogación formal de las leyes por otras posteriores, se infiere de la redacción actual y comprimida del art. 2.1 C.c. (Código Civil español de 24 de junio de 1889, reformado por la Ley de 31 de mayo de 1974)- de las normas que, apurado un crédito de elasticidad presumiblemente productivo, pierden su flexibilidad originaria. No conciben una supervivencia tocada del ala por los impedimentos de la rigidez sobrevenida. Las normas jurídicas relevan a las que -ante el ocaso de sus oportunidades flexibles y la evaporación de su imperio- no reúnen las dotes de actualización que corroboran su vigencia y ayudan a cumplir las funciones sociales dependientes de ella. El dicho inteligente que la ley no puede ser pan para hoy y hambre para mañana denota la reacción del sentimiento popular ante este aspecto de su generalidad y su fuerza expansiva.

\section{Circunstancias y particularidades que acompañan al fenómeno de la recepción y estimulación equitativas}

El Derecho es una disciplina existencial que, aunque mora en una parcela selecta del mundo del espíritu, reta fogosamente al mundo de la naturale$z a$ para inventariar el acervo de acciones y pasiones a las que -si lo aconseja alguno de los intereses generales- la Política Legislativa dedica sus competencias analíticas y sus predilecciones didácticas. El Derecho representa un auxilio que, de mayor a menor, se ha tildado de disciplina filosófica y esencialmente discursiva, de materia científica objeto de la investigación y pendiente del éxito de sus resultados, de instrumento técnico e incluso de herramienta doméstica sazonada con aderezos aristotélicotomistas. El Derecho no puede recatar sus atenciones para con las demandas -embebidas en los intereses legítimos o en otras apetencias por los bienes deseables de la vida- de las personas individuales y de los grupos que, plasmando el pluralismo de la sociedad, las ponen al servicio de sus objetivos de valor y de fin. Estas actitudes confirman -a la luz de las realidades cognoscibles y de los conflictos y/o contradicciones que afectan a sus protagonistas- la estructura de la sociedad organizada en el Estado. Pese a lo prosaico de los cometidos que explican sus funciones de disciplina doméstica, el Derecho tiene de fugitivo lo que-para la angustia y sutileza de los debates filosóficos-implicaron los enigmas del tiempo. A uno y otro conviene la proposición de que su pasado ya no es, porque dejó de serlo para suerte o desgracia de cuantos les soportaron o vivieron, su presente es o casi no es, porque -a imitación del agua vertida en una cesta- está siendo y se escapa inaprehensiblemente de 
las manos, y su futuro todavía no es, porque se subordina a un sinfín de imprevisibles acontecimientos. La mención de las circunstancias del tiempo -medida de algo tan delicado como la diligencia en el cumplimiento de las obligaciones a que alude el art. 1.104 II C.c., es decir, la sujeción de los hábitos de la persona a los sacrificios inherentes a su propia conducta- prueba la notabilidad de los arrestos invertidos en defender la causa del Derecho según el fideismo deontológico -que observan los sectores sociales más devotos de los aspectos éticos- y custodiar su etiqueta de mínimo moral. Esto empero, una de las lecturas admisibles de los arts. 1.1 y 9.2 CE (Constitución española de 27 de diciembre de 1978) -innovadora del valor superior del pluralismo político y libre de excesos hipermoralistas- sostiene que el Derecho augurado por ambos preceptos es -además de válido, como enseña la orientación normativista- un Derecho justo y acorde con la naturaleza de las cosas. El constituyente ha ingerido en el vértice piramidal del ordenamiento jurídico - no en la periferia de esa figura de la geometría del espacio- un bloque de moralidad legalizada que acapara el espacio habitable de la justicia material. El minimalismo socorrido -lugar común de la Filosofía del Derecho y de sus tradiciones didácticas-cede ante la cláusula de sensibilidad ética que los arts. 1.1. y 9.2 CE innovan y extienden a todos los pagos del Derecho objetivo.

Apelar al elemento teleológico de interpretación de las normas jurídicas no significa que, para explorar los mensajes cursados a sus destinatarios, su espíritu -infusión moralizadora- y su finalidad -objeto directo de las transformaciones- se atrapen o capturen, al uso taumatúrgico, por obra y gracia de un ingenio cuasimilagroso o de una idea feliz que no siempre gratifica al intérprete frecuentemente privado de su auxilio. Las disciplinas del mundo del deber ser resuelven problemas de interpretación cifrados en conclusiones convincentes -de óptimas apariencias- y, sin embargo, susceptibles de muchas mejoras que, ignoradas entonces, se van introduciendo y se consolidan después. Mejoras dependientes del espíritu móvil-sagaz hallazgo de los canonistas medioevales- que, sobrevolando el tiempo y el espacio, acampa en los reductos de la interpretación. Anima las normas jurídicas gracias a un elemento material -el transcurso del tiempo- y un indicativo de valor o rasgo de identidad que se adivina cuando lo impone la aplicación de aquellas. Su noticia veraz y su catalogación ordenada son el fruto de una metodología responsable, que sabe lo que quiere, y no de quién sabe qué confabulaciones políticas o precipitaciones demagógicas estigmatizadas por la indigencia intelectual. Ahí se adivinan los signos de los tiempos y las claves de acceso a las latitudes del Derecho justo. Un Derecho que, sin mengua del Derecho Positivo y sus connotaciones de equidad, emerge en los parajes de un mundo donde las colisiones de intereses jurídicos y económicos -que, a primera vista, parecen idénticas- descubren, si se escruta su interioridad con detención, los trazos que, al acusar sus diferencias, las caracterizan como iguales a sí mismas. El principio de la generalidad de las leyes hace aguas en pre- 
sencia de las anomalías que, atizando las dudas de los analistas más fervientes, debilitan los arrebatos de fe secular -profesada por la dogmática del positivismo legalista- y la magnitud de sus aportaciones.

Estas reflexiones mitigan el mordiente del principio de igualdad en la aplicación de la ley que pertenece al contenido esencial o núcleo invulnerable del derecho fundamental reconocido en los arts. 9.2 y $14 \mathrm{CE}$. No siempre existe, pese a las apariencias, la identidad o la analogía que obliga a respetar el cuerpo de doctrina de un litigio resuelto por el órgano jurisdiccional ante el que se invoca la sujeción a lo acordado. Su eficacia vinculante se alega para obtener una resolución de signo coincidente con el del anterior pronunciamiento. La emisión de la respuesta judicial es una variante de la buena fe que, según el art. 7.1 C.c., veda la falta de lealtad y corrección consistentes en volver contra los propios actos. Cabe, unas veces, replantear el problema desde perspectivas inéditas que remozan el principio de igualdad en la aplicación de la ley con razones cuya originalidad ofrece más convincentes conclusiones que las del pensamiento judicial sucedido por el que así le desaloja. Tampoco faltan ocasiones en que los hechos nuevos -que no se adujeron ni probaron en el curso de aquellos procesos- afectan al elemento histórico individualizador de la causa de pedir que identifica la acción ejercitada y/o a las excepciones oponibles de adverso. La doctrina de la sustanciación -relativa a la estructura de las acciones judiciales- y la presunción del conocimiento judicial del Derecho permiten que, sin vulnerarse la congruencia procesal y sumando un punto de flexibilidad, se eche mano de principios y normas aplicables, por vez primera, al caso debatido. Su cantidad y calidad fertilizan una justicia material que suaviza la rigidez de las respuestas aceptadas antes como paradigma inconmovible.

Amén de estos supuestos generales, cada caso tiende a adquirir una fisonomía irrepetible y única por obra del transcurso del tiempo que muda las circunstancias influyentes en su primitiva disección o añade otras que modifican su identidad o la confunden. El rigor técnico-jurídico de la solución se desploma si, para aliviar la carga de responsabilidad o acallar las voces que cuestionan la conservación del precedente, el intérprete se parapeta tras el principio de igualdad en la aplicación de la ley y reitera la invocación genérica de la seguridad jurídica. Olvida que la elasticidad de este concepto sufre operaciones de reconstitución y se utiliza para salvar las simplificaciones de su fisonomía, si hay que encarar problemas necesitados de enfoques minuciosos, y examinar pulcramente los progresos habidos en el círculo vital de las acciones interpretativas. A ello se suman los inconvenientes de que la presentación de muchas resoluciones judiciales se ciñe a resumir -sin la homogeneidad crítica ni las preferencias analíticas que distinguen a esta especie de literatura jurídica-sus respectivos contenidos, y a omitir la sutileza que advierte del concurso de las condiciones requeridas para aplicar, sin laxitud, el favor del citado principio o, si no es así, sugiere estar a la transformación equitativa de su significado y de su esencia. 
La diversidad de trato ha de fundarse en una justificación objetiva -cuya noticia no despierte dudas ni equivocidades- y razonable, libre de la arbitrariedad del pensamiento débil o torpemente monolítico, de la extravagancia de los dislates interpretativos y de la insuficiencia intelectual que, parafraseando una divertida ocurrencia, transfiere a los demás la carga de extenuarse en las tareas de la creatividad y el pensamiento.

\section{Conexiones que cabe apreciar entre la 'aplicación equitativa del Dere- cho objetivo' y la figura de la 'legislación de caso único'}

Cuando el legislador acepta el reto y corre el riesgo de obsequiar a la comunidad con un ejemplo de la legislación de caso único -que pone en la ciudad- y sienta una excepción al dogma de la generalidad de las leyes, los episodios de aplicación del Derecho, que dicha novedad implica, desencadenan reacciones y/o respuestas oscilantes entre la rebeldía de la tradición y la perplejidad del desconcierto. Las unas recuerdan el principio de interdicción de la arbitrariedad de uno de los poderes públicos que, al ejercer la potestad legislativa, parece ignorar las garantías con que los arts. 9.3 y $67.1 \mathrm{CE}$ avalan las categorías de la seguridad jurídica y la generalidad de la ley. Las otras dudan de que una acción de ese calibre no sea tan arrogante o impulsiva como, a primera vista, parece y admiten la ortodoxia interpretativa -inuevamente el mensaje del art. 3.1 C.c.!- de que, no obstante obrar así, el legislador siga estando en su sitio. Se adueña del espíritu y la finalidad de un interés que, por hipótesis, descarta la futura reiteración de operaciones que sólo se justifican en esa irrepetible ocasión.

Las diferencias sustanciales y ocultas no se captan cuando -más instintiva que reflexivamente- surgen problemas de traza idéntica o análoga, cuyo cotejo apresurado invita a elegir unas normas de Derecho objetivo que se dicen aplicables a cualquiera de ellos. No se observa que, aunque apenas perceptibles, perduran las particularidades de base que, al retirarles su condición paradigmática, invalidan el juicio de identidad o analogía. La verificación de su existencia obliga a un tratamiento -excepcional o sumamente individualizado-que utiliza los mínimos justos para resituar las cuestiones planteadas por la diversidad de fondo. El asirse mecanicistamente al principio de igualdad en la aplicación de la ley que incluye el art. $14 \mathrm{CE}$, lejos de reafirmar las pautas de la seguridad jurídica, puede incitar -según el art. 7.2 C.c.- a ejercicios antisociales y abusivos del derecho fundamental que está en juego. El valor superior de la justicia padece si este dogma -que representa el yo- se reduce a un axioma solitario y desligado de las particularidades o matices que constituyen sus respectivas circunstancias.

$\mathrm{El}$ art. 1.1 CE repara en un género próximo-comprensivo de las diferencias específicas de la libertad y la igualdad abarcadas por la justicia material- que ocupa el vértice de la piramide inventada por el normativismo 
para diseñar la figura del ordenamiento jurídico. Antes de escenificarse los ejemplos de la legislación de caso único y segregarla del campo de los privilegios odiosos, no se concebía un panorama normativo distinto del esbozado por la legalidad fundamental del Estado de Derecho liberal burgués, sucedido por el modelo del Estado social y democrático de Derecho que enmendó, hasta donde pudo, las flaquezas de su predecesor. La justicia material -de corte suprapositivo-adquiere, aquí y ahora, las cualidades de coerción impresas por el énfasis de que el constituyente hace gala para privilegiarla en el TPCE (Título Preliminar de la Constitución española). Decisión que, encumbrando el arrojo de esa prerrogativa, la erige en criterio supremo de control. Este arranca de la tarea completa de constituir para inspirar las operaciones de creación y aplicación del Derecho consecuentes con unas posturas axiológicas que, adheridas al depósito de las normas del orden natural, animan la frecuencia y la intimidad de sus contactos. Hay un factor común de fiscalización que, sobrevolando los parajes del Derecho constituido, cierra y comprime, por los cuatro costados, todo un bloque de moralidad legalizada.

Ello obliga a revisar la bondad -ya que no a exagerar la excelencia- de la legislación de caso único, expresión equitativa de la potestad generatriz de un sector del ordenamiento jurídico y no de la jurisdicción que carece de competencia para consumar, en tan atractivas circunstancias, sus anhelos de creatividad. Lleva a reflexionar - pensándolo dos veces- si no hay que criticar la tendencia a trivializar la legislación de caso único y si esta no puede instalarse, sin distorsiones ni aspavientos, en los espacios habitables que le ofrecen los signos de los tiempos. Se suple legislativamente una acción judicial que, acantonada en el sistema de fuentes del Derecho objetivo, pasa olímpicamente de muchos problemas que, estancados o arruinados en vez de resolverse, sucumben a la indiferencia y al olvido. Sobre todo si, pese a considerarse caso único el que se dice irrepetible y definitivamente consumido, los avisos de las previsiones estadísticas no excluyen las probabilidades de reiteración que, de surgir en el futuro, ha de afrontar el legislador desde una perspectiva general y a base de un modelo que, aunque técnicamente sepultado, resucita y se erige en el precedente que todavía no era.

De la lectura del art. 9.3 CE se infiere que el cuerpo de principios y preceptos de la carta política garantiza la seguridad jurídica, porque -cautivo de un compromiso pedagógico- le repugna atribuir al TPCE el estigma de un trastorno bipolar que alterna lo elástico de sus admoniciones axiológicas con el sometimiento a las pautas del normativismo. El respeto a la seguridad jurídica no pugna con la tesis -ajena a la asepsia de algunos sistemas enemigos de la genuina creatividad legislativa- de que las leyes se dirigen a lograr algo más elogiable y generoso que el servicio constitucional de los intereses generales, cuya promoción y defensa datan de su espíritu y finalidad originarios. Estos responden a la intención de los legisladores atentos al mejor y mayor número de hipótesis en que, asidua y efectivamente, se protegen las 
causas -expresivas del bien común de la ciudad terrestre- de la coexistencia, la colaboración y la participación. Lo cual no impide que -conforme al elemento histórico-evolutivo de interpretación o a las iniciativas creadoras que, además de los clásicos criterios hermenéuticos, admite el art. 3.1 C.c.- la ley adquiera los contenidos móviles o acuse las transformaciones dependientes del transcurso del tiempo y los sucesos ocurridos allí donde se aplica.

La noción del orden natural de contenido variable -precedente de las operaciones flexibles- quiso poner al día, engrandeciéndolas, las versiones más nobles de la regla central que, ordenando hacer el bien y evitar el mal, recordaba que -fuera de la buena voluntad de las acciones u omisiones de los seres humanos- nadie ni nada podía reclamar la consideración de persona o cosa absolutamente buena y exenta de servidumbres o flaquezas. Las leyes -llamadas a servir objetivamente los intereses generales que se benefician de su ofrecimiento y de sus aplicaciones especiales- han de ser justas por encima de todo, pues, a diferencia de las premisas acromáticas del positivismo legalista, la validez jurídicoformal de sus mensajes no basta para considerarlas intachablemente constitucionales. De ahí, la naturalidad -transparencia de un estado de cosas visible- y la elocuencia -convicción de resonancias múltiples- con que, fiel al sentido propio de los términos de su proposición normativa, el art. 1.1 CE da a entender que la justicia de las leyes es un requisito previo al cumplimiento de las exigencias constitucionales o las opciones del decisionismo político que, confiriéndoles la cualidad de tales, les asigna la validez imprescindible para ingresar en el ordenamiento jurídico que las asimila.

La vibración tradicional minimalista critica esta lectura, cuya calidad equitativa se asocia al prestigio de la tesis del retorno incesante de las normas yacentes en el depósito del orden natural. Se objeta que solamente encarna una de las opciones interpretativas que el valor superior del pluralismo político permite adecuar a las pautas de una comedida racionalidad, pero que no excluye otros entendimientos razonables y conformes con la legalidad fundamental. Se responde que es atrevido rebajar -cuantitativa y/o cualitativamente- las oportunidades históricas de grandeza moral de un desafío que -a partir de un ambicioso arrastre constitucional- se dirige a las zonas dormidas de las malas conciencias e invita a irrenunciables compromisos. ¿Hasta qué punto no están atormentados los planes y vivencias de cuantos, haciendo intencionadamente oídos sordos a lo sugestivo de dicha doctrina, prefieren prestar sus voces a otras versiones menos generosas?

El imperio de la ley -al que única y exclusivamente se someten, por precepto de los arts.117.1 CE y 1 LOPJ (Ley Orgánica del Poder Judicial de 1 de julio de 1985), las resoluciones de los Jueces y Magistrados integrantes del Poder Judicial del Estado- es, antes que el predominio del Derecho emanado del legislador constituyente u ordinario, la sujeción al orden natural basado en la justicia -síntesis de la igualdad y la libertad efectivas- y en lo arrebatador de una equidad que se confunde con su esencia. Nadie da por 
bueno que, so pena de aceptarse una antinomia devastadora y surrealista, el art. 103.1 CE reitere el pleno sometimiento de las Administraciones Públicas a la ley y al Derecho -acervo de normas jurídicas positivas y suprapositivasy no se reconozca -correlativa y contextualmente- que, según el art. 117.1 $\mathrm{CE}$, la jurisdicción queda obligada, con mayor razón, al respeto y aplicación de las segundas. No se sostiene en pie la idea de que el constituyente exija de las Administraciones Públicas el empleo de unas dosis de juricidad cualitativamente superiores -puesto que abarcan lo concerniente al orden natural- a las que los órganos judiciales deben tener a mano para ejercitar sus competencias y declarar la suerte de los bienes de vida que el fallo del proceso concede o deniega.

La condición de garantes de la justicia prueba lo discutible de una interpretación desentendida del tenor general del art. 9.1 CE. Se requiere una colectura sensata de los arts. 103.1 y 117.1 CE para rehabilitar los alcances del art. 1.7 C.c., cuya resituación en el marco del sistema de fuentes del Derecho objetivo es notoria desde que los arts. 5.1 y 7.1 LOPJ entraron en vigor y modificaron aquel. El principio ontológico de no contradicción -traído nuevamente a capítulo- recuerda que el ordenamiento jurídico no puede ser, al mismo tiempo, una cosa omnicomprensiva y extensa, para la actividad de las Administraciones Públicas, y otra, empequeñecida y fragmentada, para el ejercicio de la jurisdicción. Esta predisposición sicológica se optimiza con la ayuda de un Derecho objetivo que active y no entorpezca la construcción de soluciones inspiradas en las líneas de fuerza de la justicia material. Se mantiene una curiosidad constante por la intensificación de este valor y sus análisis dogmáticos.

No huelga recordar que la efímera SETS (Sala de Equidad del Tribunal Supremo) se erigió, durante la II República, con el fin-definidor de sus objetivos de justicia material- de que pensadores universitarios y expertos en actividades económicas, negocios de Derecho Privado, materias sociales y aspectos familiares se encargaran de humanizar las leyes, obviando la falta de coincidencia entre lo formal y lo material, entre lo jurídico y lo social en casi todos los dominios de la vida del Estado.

\section{Examen de las claves o señales del crédito alcanzado por el sentimien- to de equidad y el hecho de su propagación}

Aunque conexas con otras premisas axiológicas, estas ideas son algo más que el eco de las especulaciones que las han motivado. Cunde hoy la convicción de que, por obra y gracia de las inflexiones graduales de sus enunciados y de las erosiones que ha sufrido, el dogma de la generalidad de las leyes ha entrado en crisis y decaído más allá de lo previsible a lo largo del tiempo en que las contingencias históricas han mudado su fisonomía. Las conminaciones de lo existencial aconsejan tratar equitativamente 
-limando, con ocurrencias propias de un certero diagnóstico, las asperezas de las confrontaciones judicializadas- los casos embrollados en que la observancia de las normas del Derecho Positivo y el cumplimiento de la regla jura novit curia no satisfacen las aspiraciones legítimas de los interesados ni les procuran respuestas acordes con el contenido esencial del derecho fundamental de acceso a la jurisdicción que recoge el art. 24.2 CE. No solo porque los controles realizados en nombre de la justicia material se justifican constitucionalmente, sino también porque el antecedente histórico legislativo más notable -a saber, la mención capital que el art. 3.2 C..c. dedica a la equidad-conduce a su toma en consideración. La propensión invasora de esta regla -parte del Derecho previgente- ha superado la criba de depuración instituida para constatar la mal denominada constitucionalidad sobrevenida o, por mejor decir, la compatibilidad con la legalidad fundamental. Ejercicio de censura previa que, según la DD (Disposición Derogatoria) $3 \mathrm{CE}$, ha de ser individualizado y preceptivo, porque la constitucionalidad de las normas del perecido régimen paternalista autoritario no se presume irrefragablemente y, a diferencia de otros sistemas constitucionales, debe probarse mediante las oportunas valoraciones de contraste.

Aunque la afirmación parezca surrealista, el art. 3.2 C.c. pasa a ser un avance del desarrollo proféticamente preconstitucional de la seguridad jurídica que garantiza el art. 9.3 CE. La ficción invierte la cosmología cronológica de las normas jurídicas y explica el carácter cuasiconstitucional que, a partir de esos cambios, adquiere el TPC.c. (Título Preliminar del Código Civil). El art. 3.2 C.c. presiente los reparos que, lastrando los esfuerzos de la jurisdicción ávida de dar con las opciones de aplicación del Derecho justo, suscita la obligación -impuesta en el art. 1.7 C.c.- de estar al sistema de fuentes establecido. Cancelando el debate sobre la pertinencia de enunciar criterios legislativos para interpretar las normas jurídicas o abstenerse de hacerlo, el art. 3.1 C.c. intuye la complejidad de la faena y, asumiendo una actitud ecléctica, elige la primera de esas alternativas. Provee a los aplicadores del Derecho objetivo -en cuyas filas militan, además de los integrantes del Poder Judicial y de los cuerpos de juristas, cuantos exhiben la etiqueta de operadores jurídicos- de un repertorio de elementos interpretativos procedentes de la tradición. Innova una función cuasilegislativa excepcional y unas oportunidades hermenéuticas que nunca están de más y de las que se ignora hasta dónde pueden llegar sus ejercicios de imaginación y crecimiento. Cuando el cambio de las realidades sociales del tiempo y del lugar requiere encontrar reinterpretaciones de supervivencia de las normas jurídicas envejecidas por la modernidad arrolladora, los desafíos o situacioneslímite, que ampara esa licencia, permiten inclusive mudar la redacción textual de sus proposiciones y reformularlas. $\mathrm{Al}$ entendimiento literal de las leyes, que han dejado de ser pan para hoy, suceden relecturas flexibles cuyo espíritu y finalidad afianzan su valor vital y evitan convertirlas en hambre para mañana. Procuran esas reformulaciones que, sucediendo a los entendi- 
mientos castigados por la quiebra de la presuposición de la norma jurídica, inundan los espacios vacíos de la necesidad sobrevenida. Protegen la continuidad de los intereses atendibles, a la manera como -acudiendo a la teoría de la base del negocio- se zanjaron algunos problemas de los contratos conmutativos y onerosos con prestaciones de tracto sucesivo o dependientes de futuros acontecimientos.

Conviene escudriñar -en pos de la victoria que premia a los audaces y reprime los desvaríos esperpénticos- la entrada en escena de sensibilidades o corrientes pensantes cuyo ingrediente de progreso, integrado en los ejemplos de la producción legislativa, transmite a la ley una voluntad indisociable de todo el tiempo durante el que se presumen lo efectivo de su regulación y la posibilidad jurídica de aplicarla sin vacilaciones ni reservas de peso. Lo fecundo del espíritu móvil -que, unas veces, avanza inexorablemente y, otras, arranca de una feliz e inopinada idea- se opone a que la obsolescencia de las normas jurídicas provoque, sin más, la abolición consistente en su aniquilación automática. Hay que disgregar la petrificación de los objetivos $q u e$-con un conocimiento de causa limitado por los horizontes de su generación- asignó el legislador a los mandatos o prohibiciones de las normas jurídicas expuestas a tal vicisitud. Lejos de resignarse al infortunio, se ha de refrendar, contra viento y marea, la tesis de la conservación renovadora y modernizante de su imperio sobre las situaciones jurídicas expuestas a la corrección cuasilegislativa de cuantos hoy en día las aplican. Así se reconocen los supuestos de hecho que, gracias al esfuerzo de transformación, impregnan el Derecho objetivo que se beneficia de esos cambios. A diferencia de una subordinación marginal, la continuidad de las normas jurídicas depende fundamentalmente del nuevo espíritu y finalidad que estas adquieren cuando, aquí y ahora, se debaten sus temas centrales o se versa el destino de los intereses confiados a su regulación. La acción excitante del espíritu, que vivifica, prima -como subraya el mensaje del art. 3.1 C.c.sobre la letalidad de la letra que mata, porque esas normas van acompañadas de los valores vitales determinantes de su implantación en los pagos de la ciudad terrestre. De ahí, el reto del adverbio enigmático que encierra el art. 3.1 C.c., situado donde, con hartura de reflexión y perspectiva, el legislador tuvo a bien emplazarle para morigerar las abundantes y temibles dudas que ocasiona la interpretación de las leyes. Un menester ajeno al planteamiento de problemas adicionales de interpretación interior, aunque la llegada de experiencias jurídicas imprevisibles obligue a recorrer y desbrozar los caminos que anuncian sus dificultades.

Las normas jurídicas se congelan si, privadas de sus mínimos de elasticidad residual, desconocen o dan falsas respuestas a los estímulos de las realidades sociales que, debiendo inspirar su aplicación evolutiva, no engendran las transformaciones anejas a la naturaleza de las cosas. No hay entonces salida distinta de la de resignarse a lo fatal de la inutilidad y abolición indeludible de las normas que se paralizan. Resulta así de comparar el art. 5 
II C.c.89 -que solo admitía la derogación de las leyes por otras posteriorescon el art. 2.2 C.c. que, no por azar o descuido, expulsa las menciones del desuso, la costumbre y la práctica en contrario, con que el primero de ambos preceptos vedaba las tentativas de desautorizar el imperio del Derecho escrito válido y vigente. El moderno legislador reacciona de otro modo, porque, sin ignorar los efectos de esa cirugía, entiende que ciertos silencios, enfáticos y conmovedores, de las leyes son decisivos para iluminar el sentido de los términos, englobados en sus proposiciones normativas, y la inteligibilidad de los conceptos y los juicios que quieren transmitir. El art. 2.2 C.c. -consciente de su causticidad derogatoria- no ha vacilado al suprimir la cita de las contingencias agresivas y trituradoras de las leyes obsoletas de perentoria abolición. Más cauto y seguro, quizás, habría sido introducir una cláusula general que, de una vez por todas, alejase los fantasmas del miedo al vacío.

La norma jurídica se torna inservible -a causa del desuso que achica las dimensiones del Derecho objetivo previgente- si la opinión pública y la comunidad de juristas censuran su inadecuación a las realidades sociales del tiempo y del lugar en que las peripecias de su aplicación se exteriorizan. La inflexibilidad sobrevenida invalida el papel del elemento histórico-evolutivo de interpretación que, vista la atención fundamental preceptuada en el art. 3.1 C.c., deja franco el camino a las funciones cuasilegislativas de la jurisdicción. Estas salvan la subsistencia y el destino sensato de las leyes cuya madurez denota estados jurídicamente saludables o cuya senectud exige los remedios aptos para vencer el deterioro o sanar el mal de crecimiento que se les atribuye.

He ahí la clave del llamamiento a la equidad o, por mejor decir, la advertencia que, razonablemente conjugada con otras, invita a reiterar los esfuerzos constitutivamente históricos de la razón práctica. La norma despojada de su valor vital se ve abolida, pues -quemadas las naves de una excursión hermenéutica que no se ha culminado con éxito- decaen el espíritu y la finalidad que, al emprenderse la operación de salvamento, amparaban los intereses legítimos o las inclinaciones por los bienes sensibles de la vida cuya protección se les encomendaba. Estos pierden los beneficios del auxilio logrado hasta entonces, porque la norma deja de existir al neutralizarse jurídicamente sus funciones y no disponerse de un sustitutivo que eficazmente agite su inmovilidad o estado de petrificación. El art. 3.2 C.c. está donde se encuentra para paliar el deber -que establece el art. 1.7 C.c.- de que los aplicadores del Derecho objetivo se atengan al sistema de fuentes establecido. Suple la falta de instrumentos aptos para elegir la respuesta judicial que, según el art. 11.3 LOPJ, dote de una motivación que -estampada en los fundamentos jurídicos de la resolución recaída- dilucide los problemas de fondo, sin pecar de arbitrariedad ni claudicar ante las tretas del pensamiento débil. Es entonces cuando -en pos de una eficacia elevada a la segunda potencia- la equidad o dictamen de la recta razón relativiza el juego del sistema de fuentes del Dere- 
cho objetivo y usa de una metodología especial para afianzar la vocación a uno de los principios generales del Derecho. A saber, el concurso de la justicia material o la acomodación al depósito de las normas del orden natural que -actuando sobre la materia en su acepción más rigurosamente filosófica- informan el contenido de los sectores del ordenamiento jurídico. Lo recuerda el art. 1.4 C.c. cuando, de pasada y con intencionalidad aplastante, no esquiva la oportunidad de decir lo que piensa sobre este punto de doctrina.

No faltarán supuestos en los que -pese a los esfuerzos cuasinormativos de adaptar el mensaje de las normas jurídicas a las realidades sociales, cuya fijación conceptual permite ingeniosas ocurrencias, y atender fundamentalmente al espíritu y finalidad de su propósito- la irreversible rigidez de su envejecimiento obliga a declararlas inviables. La conminatoria invocación de la equidad se debe a los dictados de la recta razón y el buen sentido que, sin errores sustanciales, se redefinen y ocupan lugar en la terapia de esas coyunturas.

Una comprobación estadística -detenida y solvente- de los casos en que las afecciones incurables de las normas obsoletas las marginan del ordenamiento jurídico resalta lo importante de situar la equidad en aquellos espacios donde, fuera de toda duda o entorpecimiento, se compruebe su efectividad y se cuente con los medios óptimos para llevar al mejor de los fines la ejecución de sus funciones sociales. Hay que fomentar los procedimientos -sobre todo los de los modos extrajudiciales de composición- que acreditan su potencial transformador. Hay que ratificar los augurios de un futuro cuya elección se compense con adquisiciones inmediatas, materialmente justas y digeridas por una opinión pública consciente de su publicidad y de sus éxitos. Nace una especie de justicia popular pasiva, llamada así por la propagación del efecto didáctico a todos los reductos de la sociedad pluralista en que esa difusión acaece. Se acrecientan las demandas que, acuciados por la inquietud equitativa, reciben los legisladores cuando escuchan las voces de la sociedad o de las comunidades que, rompiendo sus silencios, exigen la incorporación cualificada de las demandas y los contenidos de equidad a las manifestaciones del Derecho en vías de constituirse.

No es el momento -porque de ello se ha hecho cuestión otras veces- de volver sobre el tema de la aptitud para juzgar en equidad de los jueces profesionales que, por imperativos del sistema, sirvieron, mientras se hallaban en activo, las funciones de juristas independientes, aplicadores del Derecho objetivo en vigor y únicamente sometidos al imperio de la ley. Tampoco es el caso de compararlas con las de los juristas que, provistos de una formación especializada, se dedican -exclusiva o preferentemente- a la reconstrucción y/o edificación de la equidad. El panorama general es más variado. Existen testimonios históricos -como los que abrieron los caminos del Derecho Internacional Público o nacionalizaron las bases del Derecho Hipotecario- de descubrimientos y adelantos cuyo prestigio provino de lo espontá- 
neo y enérgico de las reacciones desencadenadas frente a los medios institucionales que, por hostilidad, los contrariaban o, por desconocimiento, ignoraban lo mejor de sus merecimientos y valores. Se jugaba desventajosamente a falta de la asimilación generalizada, incondicional y devota de unas verdades que aún no habían pisado tierra firme ni adquirido la difusión consiguiente a su peso específico. Sin decir nada más, mucho enseñan y algo hay que aprender de estos ejemplos y aleccionamientos.

Los aplicadores del Derecho -integrantes de los órganos de la jurisdicción o intérpretes extrajudiciales- tienen que adoptar, con frecuencia, soluciones que, bajo el imperio de la ley, pugnan con lo que la equidad exige y se olvidan de sus excelencias. Carecen de alternativas tentadoras o de rumbos fiables de navegación para culminar la tarea que llevan a cabo. Cuando estos entorpecimientos conmueven a una opinión pública dispuesta a contrariar sus irrupciones, se constituye un estado de crisis ético-jurídica que indica el camino corrector a seguir y, hablando con propiedad aristotélica, se decide a llamar por su nombre a uno de los calvarios de la aventura equitativa. Los reveses debidos a la imposibilidad o la dificultad extraordinaria de actuar equitativamente enturbian el círculo vital de los devotos del Derecho justo, si bien las decepciones que acarrean -lejos de atenuar el mordiente de los procesos de reacción, intimidar a sus protagonistas o inducir a un entreguismo resignado- refuerzan el espíritu y la determinación de rebeldía frente a los agravios que la equidad padece. Estos experimentos conciencian de la servidumbre del fracaso de los arbitrios de justicia material a los que el legislador deniega el espacio y las oportunidades propicias a la recepción de la equidad. No es menos de intuir la grandeza del sentimiento de la propia dignidad que -inspirando las modalidades de reacción- propugna un futuro en el que la racionalidad absoluta y flexible del sistema judicial compense a cuantos, abatidos por esos desalientos, no desesperan de saciar el hambre y la sed de justicia de sus ilusiones pendientes. Impidiendo, por encima de todo, que el sentimiento de equidad y las emociones que apareja se vuelvan irreconocibles y que -andando el tiempo que agrava lo doloroso de su ausencia- se esfumen en el nostálgico paisaje de uno más de los paraísos perdidos.

Los cultivadores de la equidad a tiempo completo -más puestos al día de sus peripecias y accidentes- la manejan con la soltura propia de quienes, sin adoptar una postura antisistema, prefieren acudir a los modos usuales de composición para imaginar, discurrir y resolver -auxiliados por el uso equitativo del Derecho- conforme a las reglas del depósito del orden natural. Cuantos, sin formalismos técnico-jurídicos, apelan reflexivamente a la equidad que, en todo o en parte, sustituye a las normas del Derecho Positivo, no ven frustrados sus propósitos, pues, por definición, acondicionan los ingredientes de un sentimiento equitativo cuyo carácter institucional obliga a mucho más que a atrincherarse en las zonas tácticas de la resistencia. Quienes, en cambio, han tropezado con las barreras insalvables del imperio de la 
ley contabilizan los reveses de las ilusiones equitativas frustradas por lo imponente de esos desencantos. Su ambición estimula un ejercicio tenaz de reflexión sobre lo indispensable de difundir y asentar, sin dar un paso atrás, los temperamentos de equidad que la sensibilidad de sus descubridores asu$m e$, si, una vez concretados, los sistematizan y aplican saludablemente. Huelgan otras consideraciones para mostrar lo razonable de estos argumentos. El entendimiento y la voluntad de los juristas son más admirables cuando encaran problemas de dificultad reconocida -como los relativos al debate sobre la exaltación de la equidad-que si sus desvelos de aprendizaje equitativo no sufren esas trabas y gozan de aportaciones formativas que no siempre aprovechan exhaustivamente. Algo que, sin constituir piedra de escándalo, ocurre hoy con alguna frecuencia.

El apelar a la equidad, cuando su intervención apremia, salva algunos fracasos de la aplicación del art. 3.1 C.c., una de cuyas reglas hermenéuticas -rectius, la potestad cuasilegislativa excepcional que asiste a la jurisdiccióndeja de actuar si la obsolescencia de las normas jurídicas invalida el esfuerzo de modernizarlas mediante las realidades sociales -del tiempo y del lugar- que convergen en su aplicación. La relectura del art. 3.2 C.c. muestra cómo lo sorprendente de esos cambios aconseja remedios confirmados, más tarde, por la letra y el espíritu de la legalidad fundamental.

La estructura del ordenamiento jurídico -fundada en la correlación de los arts. 1.1 y $9.1 \mathrm{CE}$ - presupone que, además de formalmente válidas, las normas que lo integran han de ser justas, como conviene a su carácter de protectoras naturales de la libertad y la igualdad. Lo sensato de esta proposición vence las tentaciones de atenuar el mordiente de los imperativos ético-jurídicos del art. 9.2 CE y negarle la cualidad de heredero del art. 3 II CI (Constitución italiana de 27 de diciembre de 1947) que resurge en el art. 9.IV EAPV (Estatuto de Autonomía del País Vasco de 18 de diciembre de 1979). Aquellos preceptos no pueden menos de mantener esa exigencia. La justicia reintegra -absorbiéndolas con rigor y coherencia extraños a cualquier maridaje artificioso- la libertad y la igualdad que, como la cláusula transformadora y social encarece, los poderes públicos han de proteger contra las restricciones que las hieren de muerte, si intentan suprimirlas, o hacen desmerecer su plenitud, si erosionan los valores ejemplares de su efectividad.

Cuando la regla del art. 3.2 C.c. puede aplicarse sin obstáculos, las normas del orden natural de la equidad no se discuten y se acatan. Su invocación preconstitucional de la justicia -respaldada por la letra y el espíritu de los arts. 1.1 y $9.2 \mathrm{CE}$ - forma parte del ordenamiento jurídico postconstitucional que la recibe de buen grado. Tampoco adolece, a la luz de la cláusula catártica de la DD $3 \mathrm{CE}$, de la llamada impropiamente inconstitucionalidad sobrevenida y se caracteriza por todo lo contrario. No peca de inadecuación a los principios y preceptos constitucionales y se armoniza, sin estridencias ni fisuras, con la moral paradigmática de la legalidad fundamental. 


\section{Valoración del impacto equitativo en cuanto a la proteccion y garan- tía de los derechos subjetivos e intereses legítimos a que sus repercu- siones alcanzan}

He ahí la moderación visible -debida a reflexiones morales que se fundan en la idea de liberación- de un principio de seguridad jurídica subordinado a la demanda de justicia que se dirige a los legisladores positivos. Son varios los modos con que la equidad se habrá de ponderar en la aplicación de las normas jurídicas.

El primero de ellos -omnicomprensivo y exigente- requiere comprobar si la norma jurídica aplicable merece la consideración de justa, o sea, de saludablemente persuasiva, amoldada al dictamen de la recta razón, plegada al buen sentido y exenta de taras descabelladas o arbitrarias. Un juicio desfavorable o negativo puede llevar a suspender su aplicación -con eficacia limitada a los ámbitos subjetivo y objetivo de la controversia- o a plantear, por vía del art. $193 \mathrm{CE}$, una cuestión de inconstitucionalidad que, arguyendo la contradicción con los arts. 1.1. y 9.2 CE, proponga la declaración de nulidad de aquella o la fórmula reinterpretativa que, sin llegar al punto de abolirla, señale las hipótesis en que, por no mediar el vicio atribuido, tampoco se aprecia menoscabo de la justicia material.

Otro entendimiento -de proporciones medias- cercena o suprime, en función del rigor equitativo con que se interviene, solo una parte de las consecuencias de la norma jurídica cuestionada. Se proscribe y evita la subsistencia de parcelas o zonas viciadas cuya cauterización repone la dosis de sanidad residual que depura la regla de Derecho objetivo y frena la metástasis de sus componentes patológicos.

Un último significado admite que el adverbio «... expresamente...» -empleado en el art. 3.2 C.c. para indicar cómo y cuándo puede el legislador autorizar un juicio de equidad indivisible e íntegro- no solo quiere decir «... de modo literal y terminante...». Al debatirse la interpretación del art. 1.131 C.c. en el régimen de las obligaciones solidarias, prevaleció la tesis de que esa parte invariable de la oración también podía entenderse como sinónimo de «... inequívocamente». Conclusión que, exportada a la regla del art. 3.2 C.c., confiere al enjuiciamiento de equidad un alcance que amplifica la lectura originalista de su recepción. El sentido propio del adverbio desborda, gracias a esa elasticidad, el exclusivamente literal, ya que, según el art. 3.1 C.c., lo propio es el género cuyas respectivas especies residen en lo textual, de una parte, y en lo plausiblemente razonable y lógico, de otra.

La excelencia de descansar en la equidad se predica de las resoluciones judiciales en que, ante el sentido propio del verbo conjugado, la congratulación moral e intelectual -deparada por la identificación con el concepto de lo justo- dimana de una comprensión espontánea, de la bondad de las vibraciones emotivas y de su corajudo poder de convicción, desechando cuanto, por artificioso o forzado, se encuentra fuera de lugar. Descansar no es asir- 
se mecánicamente -ante los riesgos de perder el norte- a la norma equitativa rectora del problema, sino cuidar de que, sin razonamientos fatigosos ni discursos traumáticos, lo justo -expresión emblemática del bien que tiende a difundirse- fluya naturalmente del sentimiento de la equidad inspiradora.

La operación jurídica feliz del uso equitativo del Derecho se funda en la acertada selección y en la aplicación materialmente justa de las normas del orden natural que, a ritmo galopante, invaden muchos de los espacios ocupados por el fervor del positivismo legalista. Aunque el positivismo no va a batirse en retirada ni abriga de lejos semejante propósito, sí que aprecia el tamaño de las razones aducidas y debe atribuir a la equidad el papel que le incumbe jugar en los procesos de producción de las normas de Derecho objetivo. Estas han de responder a interlocuciones sociales auténticas -merecedoras de llamarse así- y no a la decisión de los legisladores que, tras fabricarlas a la medida de su voluntarismo político, las trasladan al ordenamiento jurídico. De ahí, la obligación de difundir -en cuanto parte del contenido esencial o núcleo invulnerable del derecho fundamental reconocido en el art. 20.1 CE- el cuerpo de información veraz que, con la diligencia propia de las peculiaridades del caso, divulgue las ventajas de la penetración de la equidad. Provocación, avance y recepción que -lejos de suscitar la indiferencia o la inmersión en el olvido- se predican de los mensajes históricos notables que, como el relativo a la importancia y la propagación de la equidad, toca a todos asimilar aquí y ahora.

\section{Reflexiones que suscitan el fenómeno de la generalidad de la ley y la probable crisis de su preponderancia}

El Derecho establece los niveles de generalidad con que sus mandatos y prohibiciones -tendentes a ofrecer, sin oquedades ni vacíos, regulaciones exhaustivas- ordenan el mayor número de los episodios conflictivos previsibles y emergentes en los contactos de la vida individual y social de relación. Ampara intereses que, pugnando por prevalecer, obtienen la tutela justamente rehusada a otros incompatibles con su permanencia. El proceso generalizador de las soluciones del tratamiento de conflictos se compone de una serie de actitudes notables. Hay percepciones de principio, llamativas y toscas, cuyo rudo apetito de justicia material llama poderosamente la atención y afluye a una cautividad emocional. Le siguen tentativas -no menos incipientes- de seleccionar, mediante propuestas jurídicamente inobjetables, las cuestiones relativas a unos intereses colectivos cuya policromía -en el todo de la sociedad pluralista o de los grupos encargados de mantenerla erguida y no desvertebrarla- evidencia la generalidad de las normas que velan por su suerte. Un paso más, y se vislumbran los avances que -alzando el velo de las falsas pretensiones sociales y divisando las auténticas- emprende e intenta culminar la Ciencia de la Legislación o Política Legislativa. Lo contrario de 
la ligereza y de las prisas con que operan los legisladores incapaces de advertir las mudanzas -relevantes o harto sensibles- que el Derecho Positivo registra en el curso de una esperanza de vida breve o duradera. Cuentan, en fin, los resultados -judiciales y extrajudiciales- que acreditan esa generalidad y el cumplimiento de las obligaciones destinadas a satisfacer las demandas sociales que de antiguo los vienen reclamando.

Este proceso no se exime de las impredecibles amenazas del futuro ni del cortejo de degeneraciones o efectos perversos que aminoran su velocidad de crucero o tuercen la rectitud de sus aspiraciones. Anomalías que desconciertan y cohíben cuando, sin interposiciones nebulosas, se enfoca su desoladora panorámica y se diagnostican los males que llevan consigo. Acobardan a la opinión pública, pendiente de sus justas reivindicaciones, y destruyen las ilusiones de salvar -a través de una imagen amable del verdadero rostro del ordenamiento jurídico- una generalidad expansiva que -hay que repetirlotiende a difundirse, porque da fe de las aportaciones hechas, en nombre del bien, a la causa de la defensa del Derecho justo. La generalidad gravita sobre la base física o ámbito territorial de la soberanía política del Estado legislador, más allá del cual son jurídicamente inestables y, a veces, surrealistas las tentativas $-i$ debidas a las compulsiones egocéntricas, al uso político del Derecho o a la devoción por la justicia material?- de una desorbitada irradiación. La generalidad vence a la fugacidad del tiempo y explica la infalibilidad histórica -distinta de una inerrancia extraña a las disciplinas del espíritu- que concibe el Derecho como la herramienta indispensable para proveer a las condiciones de la coexistencia, la colaboración y la participación de sus destinatarios. Tres constantes de la definición de un bien común que, según la evolución del pensamiento secular y sus connotaciones neotomistas, coincide con la moderna idea del acervo de los intereses generales que cita el art. 103.1 CE. Sus rasgos diferenciadores afectan a la sociedad pluralista o a los grupos sociales significativos que, a la luz de los arts. 9.2 y $203 \mathrm{CE}$, congregan a los individuos cuya libertad e igualdad efectivas proporcionan las claves de su prosperidad.

El Derecho modera los antagonismos que -ante el alud de los conflictos sociales, hostiles a un quietismo sin asomos de cambio sensible, y el axioma de que lo módico de las libertades impone ocurrencias solidarias para repartirlas - enfrentan a las personas físicas y a las comunidades de la sociedad pluralista. Sumando un elemento espiritual al componente mecanicista o material de las colectividades escuetas o grupos inorgánicos, el Derecho cuida de animar, como apunta el art. 9.2 CE, las acciones transformadoras de los seres humanos que -en las situaciones referidas por los arts. 9.3, 10.1, 15, $17.1,25.2,40.2,41,51.1$ y $129.1 \mathrm{CE}$ - combaten las afrentas infligidas a su dignidad, rechazan los atropellos de sus bienes y/o derechos, y denuncian su indefensión frente a las violaciones impunes de su elenco de seguridades.

No obstante lo pésimo de estas conjeturas, la relativización del imperio intelectual y material del Derecho Positivo y las objeciones que motiva no 
borran la evidencia de que sus principios y preceptos se mantienen enhiestos y al alcance de sus consumidores. Lo acreditan los signos de una civilización cointerpretada por los legisladores, los jueces y los agentes sociales que, gracias a las orientaciones y doctrinas con las que están comprometidos, resaltan los méritos de su contribución, subrayan los defectos de sus involuciones y proponen las renovaciones coherentes con el espíritu de cambio. Las contradicciones se agravan observando que -pese al arraigo del Derecho objetivo, en los pagos del Estado social y democrático de Derecho, y la resistencia a desahuciarle de sus fortificaciones conquistadas - la excelencia de la generalidad de las leyes se desdibuja en ocasiones y se calma el tono de los elogios incondicionales que se le dedicaban. Los conflictos de gran cabota$j e$-que, a expensas del hecho globalizador, gozan de una frecuencia y fuerza torrenciales- reciben de la ley un tratamiento achicado, cuya juricidad -que no coincide siempre con la justicia de fondo-refleja desteñidamente la generalidad que se disipa. Los mínimos justos de ese tratamiento se evaporan en los espacios lagunosos -repentinos y atípicos- de los conflictos que, frustrando las expectativas optimistas, impiden vaciar el contenido del depósito de las normas del orden natural de la equidad en las pautas de una justicia material que restaure la normalidad de las relaciones sociales empobrecidas o maltrechas.

Cada vez decepcionan y fatigan más los esfuerzos que, hasta la extenuación, dedican los aplicadores del Derecho a perfilar las aristas de la historia del caso, limar sus asperezas y acoplar sus perfiles a la generalidad ordenadora que se prefiere cultivar. Ello sucede aunque las reglas pobladoras del ordenamiento jurídico respeten la plenitud del sistema de fuentes del Derecho objetivo que permite subsumir el problema en la letra y el espíritu de unas normas elegidas impecablemente. La tesis de que, para sortear los reparos debidos a la existencia de las lagunas del Derecho, bastan las fuentes secundarias y terciarias, mitiga, sin darle salida, el problema del cumplimiento de la prestación de justicia que los aplicadores del Derecho objetivo adeudan a los protagonistas de sus controversias. Estos tienen derecho a obtener una declaración sobre el tema de fondo que, independientemente del signo favorable o adverso del fallo recaído, reposa en la aceptación de la solvencia de un discurso acomodado a la regularidad del Derecho constituido. No por ello se logra el óptimo de la justicia material que, aunque imposible o muy enojosa de perfeccionar, persiguen las demandas sociales que tenazmente aguardan las respuestas de impregnación equitativa.

La lectura pausada del art. 5 II C.c.(89) -sucedido por el art. 1.1 C.c.enseña que, conforme al sentido propio del adverbio empleado, han sido y siguen siendo escasas las oportunidades que la ley tiene de aplicarse exactamente al punto controvertido. La exactitud presupone una individualización insustituible y delicada, que no emana, sin más y automáticamente, de la nota de generalidad previa al esfuerzo de la subsunción o al encaje del episodio histórico en el supuesto fáctico de la norma jurídica. Esta es apli- 
cable, pero casi nunca exactamente, si se repara en las estadísticas procesológicas que acusan laxitudes ajenas a la exactitud irreprochable de corte académico que - ¿acaso precipitadamente?- presumió la euforia codificadora. Ante lo perentorio del adverbio empleado y lo silente del Derecho consuetudinario del lugar, el art.5 II C.c.(89) situaba en los umbrales de la justicia material e invitaba a servirse de una fuente terciaria o principio general del Derecho cuya invocación de la equidad incorporaba la palpitación y el sentimiento de lo justo. A falta de una esmerada exégesis de lo que la noción de ley exactamente aplicable al punto controvertido suponía, se despreció un aspecto de la imaginación y el ingenio -típicos de la sensibilidad interpretativa de entonces- con cuyos cualificados pareceres se contaba. Se imprejuzgó el alcance de un adverbio de modo imprescindible para delimitar el universo equitativo subyacente a la redacción original del art. 5 II C.c.(89). Acercándose a este cúmulo de problemas, la teoría egológica del Derecho les dedica reflexiones muy clarividentes.

Se objeta, frente a la aplicación generalizada de la ley, que los conflictos judicializados dependen de las variables acepciones de la idea -novedosa y un tanto complaciente- de la efectiva tutela judicial y de las condiciones que, subjetiva y objetivamente, limitan las vinculaciones al efecto de cosa juzgada material. No parecen contar las perturbaciones sociales -efectos secundarios o, como la nomenclatura en boga gusta de bautizarlas, consecuencias colaterales- que afectan a situaciones jurídicas conexas con el debate abierto, ni la tangencia o la interpenetración de episodios que, acusando las resonancias del conflicto, complican su identificación inequívoca y empañan la visibilidad de su imagen.

Hay que adoptar métodos convincentes de disección de las resoluciones judiciales -distintos de las abreviaciones que omiten las analogías y diferencias entre decisiones que, coincidentes a primera vista, están lejos de serloe intensificar los esfuerzos por advenir al fondo de las cosas. Muchas rebajas de la justicia material derivan de simplificaciones conceptuales y históricas que una reflexión más detenida puede y debe poner de relieve, subrayando las imprecisiones y/o defectos que incurren en análisis superficiales, fomentan las ceremonias de la confusión, prestan un flaco servicio a la verdad e impiden especificar las variedades provechosas del pensamiento judicial.

\section{Ventajas inherentes a la divulgación del valor de la equidad, como reflejo de la justicia material, y a la puesta en práctica de sus opera- ciones}

Abundan los ejemplos de proyectos tecnológicos, sociales o económicos cuya trascendencia -notoria y duradera- requiere aglutinar indivisiblemente las voluntades de cuantos, racionalizándolos esmeradamente, se han pro- 
puesto llevarlos al mejor de los fines. La naturaleza y la magnitud de esos planes les confieren una complejidad onerosa que, durante su ejecución, puede provocar divergencias tan lógicas como imposibles de prever hasta la aparición de sus reparos. Tales anomalías o disidencias de criterio solo se salvan, so pena de un irremediable fracaso, con los temperamentos de equidad que -al pacificar las contradicciones surgidas y acortar las distancias que entre ellas median-preservan la identidad de los objetivos centrales del proyecto iniciado, fortalecen su fisonomía y animan la voluntad de culminarlo. El acceso a la jurisdicción no es la mejor de las opciones en casos que, como estos, se distinguen por su tecnicismo embrollado y por lo letal de las demoras debidas a tales objeciones. Puede hacerse alguna precisión al respecto.

Cabe que, mientras avanzan las actividades de proyectos o planes de alguna entidad, quienes comparten los objetivos fijados y se precian de su elección afortunada, formulen reparos dirigidos a que, previo examen de su alcance, se decida si es dable o no modificar ciertos contenidos parciales del trabajo en curso. No se trata de disidencias accesorias ni de problemas de menor cuantía, aunque sus partidarios presumen, de la mejor fe, de que la incorporación de sus propuestas mejorará la eficacia de un proyecto que nadie quiere entorpecer. En pro de esta actitud se aduce que las líneas de esfuerzo -ya trazadas y en vías de un desarrollo regular- respetan las previsiones básicas de origen y que se mantiene la adhesión sustancial de los defensores de unas tomas de posición accidentales que no astillan ni pervierten la coherencia de los ideales comunes. Ni de lejos pretende abrirse un frente rupturista que deshaga el trabajo bien hecho e impida continuar el que se halla pendiente de realización. Las filas se cierran en torno al propósito de salvar, cuanto antes, las dificultades expuestas y de proseguir una tarea unánimemente aceptada, cuya perfección aguarda el momento de darla por hecha en condiciones, erguidas y animosas, de solidaridad y de confianza mutua.

El éxito de lo proyectado requiere adoptar posturas colectivas que eviten los desmerecimientos arbitrarios de las parcelas de su totalidad, so pena de aceptar - contra los fueros de la sensatez- que la explosión de un reparo destruya el valor absoluto de la operación afectada por la disidencia. Hay que pacificar y reponer celosamente la duración natural de los espacios de tiempo necesarios para concluir una tarea incompatible con tardanzas nocivas que agostan la utilidad de los medios y la consecución de los fines a que se enderezan. Sus objetivos sobreviven y no tienen por qué padecer la máxima crudeza de las contradicciones que, aunque surgidas tempestivamente, amenazan con paralizarlos o mermar la velocidad de crucero que les es debida. El valor de lo social condena las reacciones -impertinentes y petrificadasque, a través de estos cismas domésticos, socavan la fe en la realización del programa previsto y en la calidad de fisonomía. Según las experiencias verificadas y vividas, las cosas son así y no de otra manera menos agresiva para 
quienes soportan las cargas de enfrentarse a los cambios y gestionar-serena y positivamente- sus vicisitudes.

No es aconsejable recurrir al remedio consistente en judicializar estos conflictos. Una o más disidencias -incluso las que median entre lo sustancial y lo accidental del proyecto- causan fricciones de calibre variable entre cuantos comparten la ilusión por el éxito del programa. Las obcecaciones de la condición humana pueden trocar en hostilidades radicales -más propias del egocentrismo discrepante que del amor a la verdad puesta en tela de juicio- las diferencias que, sin ser antagónicas, se defienden con el ardor suficiente para constatar que, aunque importante, lo debatido es accesorio respecto a la naturaleza principal de la finalidad pactada. El radicalismo borra la coafección imprescindible para apreciar lo baldío del enfrentamiento -desproporcionado con las circunstancias que le determinan- y apresurarse a disolverlo. Cualquiera que sea la suerte de una discrepancia de arte menor, su superación - pasando página - condiciona el éxito de una labor cuya continuidad debe verse mínimamente afectada por tales incidencias. El efecto no puede ser más lastimoso si, en vez de conseguirse una solución equitativamente aceptable, el triunfo de un parecer disconforme se eleva intransigentemente a elemento esencial de esa continuidad. Las asperezas del proceso judicial -dirigido a zanjar la polémica-y el ambiente de hostilidad en que se inscriben determinan que el desacuerdo sobre algo secundario haga trizas la reciprocidad central e indivisible, que ha de primar sobre lo periférico de las disidencias habidas, y esterilice una empresa digna de mejor fortuna.

La consolidación de las crisis menores lleva frecuentemente a desistir de iniciativas futuras en que -dadas las características del proyecto tocado del ala- el dinamismo de la libertad de empresa en una economía de mercado implica el ejercicio de un derecho función, con las connotaciones que, a la luz del art. $38 \mathrm{CE}$, esta calificación acarrea. El fracaso de algo tan delicadamente proyectado nace de un desacuerdo que -si, a primera vista, parece secundario, porque no es otra su naturaleza- se promueve en términos cuyo radicalismo impide salvar una dificultad superable hasta entonces. No se falta a la verdad añadiendo que la judicialización del problema va más allá de un mal menor y es excesiva para abordar las objeciones que rechazan una terapia de efectos explosivos. Amén de los retrasos y del cúmulo de perjuicios intuibles, los enfrentamientos de la contienda judicial evaporan, sin visos de recuperación, el espíritu de cooperación y diligencia indispensable para rematar un proyecto que, si antes era apetecible y útil, llega a paralizar la prestación normal de los servicios esenciales adeudados a la comunidad. Una exigencia que, de pasada, late en los arts. 28.2 y 37.2 CE.

Piénsese que asimismo se está jugando con el tiempo. Las demoras que la lentitud del proceso judicial y la secuencia de las impugnaciones admisibles -fruto del encono y/o la exacerbación del amor propio- imprimen a la ejecución de un proyecto cuya celeridad es capital, hieren de muerte el tracto del programa previsto y quebrantan la regularidad de su ritmo. Ha surgi- 
do una fuerza mayor que, al romper la continuidad de las actividades afectadas, desata incomodidades y sospechas que incitan a la voladura incontrolada del espíritu de cooperación. Desalienta la imposibilidad de respetar los plazos del cumplimiento convenido y reanudar una tarea que habría concluido -gracias a la solución del conflicto- de no haberse interpuesto esa tardanza desproporcionada. Toda una carga de profundidad desordena, cuando no aniquila, lo que ha sido objeto de una minuciosa racionalización. Hay que recomponer las previsiones sobre la prolongación del trabajo afectado e iniciar la excursión consiguiente en busca del tiempo perdido. Está entonces a punto de esfumarse un elemento indispensable para cortar la acritud de los enfrentamientos y mantener ilesa, sin riesgos de dislocación, la base del negocio que aglutina los elementos originarios del proyecto.

Las acideces -cuando no la saña de los enfrentamientos procesales que desgarran la uniformidad de los criterios aptos para el triunfo de las operaciones principales- y la congelación o el cambio anómalo de las actividades a que las disidencias se refieren, amenazan el tratamiento -expeditivo y justo- de problemas que no pueden continuar irresueltos más allá de su momento de inflexión, ni alterar la regularidad de las funciones sociales y económicas que abarcan. Hay que impedir las erosiones derivadas de acudir a la jurisdicción para esclarecer puntos cuya atención rebasa la capacidad de la que -con los prejuicios de una efectividad minimalista - se denomina efectiva tutela judicial. Recomendable es apelar, sin titubeos, a los modos de composición que prestigian el crédito del tratamiento equitativo y amparan los intereses abocados, si así no se reacciona, al injusto fracaso de unas apetencias que pierden la oportunidad de ascender al rango de verdaderos contenidos de derechos subjetivos o situaciones jurídicas afines.

\section{Exaltación constitucional del sentimiento equitativo y de las energías determinantes de su 'efectividad transformadora'}

La decisión de recobrar la asistencia de la justicia material, fomenta las tentativas -imaginativas y acuciantes- de atribuir a la equidad y a las variantes ético-jurídicas de su divulgación un espacio habitable para diagnosticar los defectos del Derecho constituido y engrosar algunas simplificaciones. Cunde la convicción de que, sin demérito de la gran aventura que culminó el modelo del Estado social y democrático de Derecho y esculpió sus trazos generalizadores, las insinuaciones individualizadoras -comprometidas con la tutela de la dignidad individual- aumentan las oportunidades experimentales y el tino de sus orientaciones. Nadie ignora -so pretexto de adherirse a verdades que, antaño inamovibles, han resultado no serlo o acaso serlo menos - lo temerario de apostar sin condiciones por una generalidad del Derecho que, despertando explicables reservas, no se concilia con las progresivas mutaciones del semblante de las normas jurídicas. 
Los ejemplos -sugerentes, a primera vista, de una contradicción en los términos- de la legislación de caso único, confirman, cuando no encierran un privilegio abominable, que, en más de una ocasión, parece haber perdido el norte la nave que, sin aparentes sobresaltos, surca los mares en que el Derecho objetivo dispersa sus mandatos y prohibiciones. El legislador -consciente de las afinidades de los hechos cuya reiteración y notabilidad justifican la necesidad de las leyes- hace, por una vez, tabla rasa de su carácter impersonalizado y general. Para simplificar el raciocinio deductivo de las resoluciones judiciales, prescinde y dispensa de una o más de las operaciones de subsunción acostumbradas. Innova un modelo de legislación excepcional que no descansa en prejuicios suspensivos de la generalidad. Decide equitativamente una cuestión -modesta o menos relevante- que, sin inscribirse en el marco excelso de los intereses generales, atañe a los intereses legítimos cuyos portadores ostensibles son las personas físicas o los grupos intermedios en que, según los arts. 9.2 y $20.3 \mathrm{CE}$, se integra el individuo para estabilizar la sociedad y afianzar sus compromisos de transformación.

La veneración de la igualdad se funda en el axioma filosófico que, lejos de hacerla consistir en dar a cada uno lo mismo mediante las acciones generalizadoras habituales, requiere fijar las pautas de individualización equitativa que deslindan lo que le pertenece y se debe poner a su alcance. A saber, la parte que le toca en el reparto de las existencias de una justicia material cuya disponibilidad es -dentro de la ciudad terrestre- la de unos bienes y derechos escasos que difieren de los ejemplos de malversación ofensivos para con la equidad y socialmente escandalosos. Su adjudicación viene dada -con sensibilidad equitativa y sin los raptos de animosidad confiscatoria a que, de vez en cuando, asienten los legisladores- por lo palpable de unas privaciones tan evidentes como convulsivas.

Nada de ello tiene que ver con la insolente predicción marxista que, desvelando el verdadero rostro del que se dio en llamar fin de la Historia, auguraba unos escenarios de convivencia idílica, purgados de emulación competitiva y proyectados para dar a cada uno según sus necesidades -sujetas a un insaciable crecimiento- y exigirle conforme a unas posibilidades fáciles de escamotear o reducir. Se incentivaba así la holganza de cuantos, diciéndose más necesitados, se solazaban con el fraudulento designio de rehusar los actos debidos de cooperación y adueñarse, voraz y simultáneamente, de los frutos del esfuerzo ajeno. Para incoar en equidad los procesos de igualación pendientes, se han de desigualar los estados de cosas que, pese a las falaces apariencias de analogía o semejanza, destilan la sustancia de lo que, haciéndoles ser ellos mismos, los identifica, sin equívocos, y los distingue de los que están lejos de serlo.

La jurisdicción se toma, si es preciso, el trabajo de convertir el Derecho en justicia por medio de estas comprobaciones, pero -si, a falta de ley, no puede hacerlo- el legislador de caso único no se cruza de brazos y espera a que, según el principio de justicia rogada y el juego del sistema de fuentes 
del Derecho objetivo, los órganos judiciales apliquen la costumbre o los principios generales del Derecho a que remite el art. 1.7 C.c. La modalidad que, superando esas dificultades, constituye una acción cuasijurisdiccional del Poder Legislativo trasluce la reacción equitativa del legislador ante una realidad injusta cuyo desafio le sorprende. Ello impide tachar de privilegio el remedio adoptado para corregirla. La operación es perentoria, aunque el riesgo de daño de los intereses generales -debido a la subsistencia de ese entorpecimiento- parezca mínimo y aun discutible. El legislador responde a una obsesión testimonial preponderante, en equidad, sobre una exigencia técnico-jurídica -la de la generalidad de la ley-que no comulga con las iniciativas de este signo. La situación recuerda, guardadas las distancias, una incursión en mora legislativa que ha de rectificarse de inmediato. Liquidando el estado de cosas injusto, el legislador se mueve en circunstancias que no son de interés general ni desigualan materialmente a ciertas personas o grupos, pero responde al llamamiento de la fuerza moral que marca el ritmo de sus compromisos normativos. Constata lo indeseable de una situación que escapó a su capacidad de percibir y de prever, aunque, al cerciorarse de su gravedad, cuide de sanarla con el mismo esmero -constitutivo de la solicitud y diligencia exigibles- que si, ya conociéndola, dispusiera de remedios aptos para impedir su inopinada emergencia y sus inconvenientes. El que no haya constancia -aunque se pueda dar a corto plazo- de una demanda social extensa y respetable, no excluye que, fiel a la naturaleza de las cosas, la legislación progrese con la misma energía que si la localización del caso único fuese notoria tiempo atrás y exigiese el amparo que se le otorga de presente. La fórmula de la cláusula transformadora y social del art. 9.2 CE explica lo novedoso de este pensamiento y lo equitativo de sus capítulos experimentales.

La obsesión por promulgar un Derecho justo -fruto de las auténticas demandas sociales y no del pensamiento o la piedad de los deseos- ha sido relativamente ajena a la testarudez positivista de los sistemas jurídicos modernos. El examen de las innovaciones del constituyente descubre iniciativas de signo contrario. Esta ilusión no solo ilustra pedagógicamente -decidiendo si son o no justos- los actos de aplicación del Derecho objetivo. También persigue que -ante la comunión del valor superior de la justicia material con la modernización de la equidad- prevalezcan los resultados de una irrupción beneficiosa y sugestiva.

Los arts. 1.1 y 9.2 CE proyectan sus haces de luz cegadora sobre el art. 3.2 C.c. - victorioso en la prueba de depuración que establece la DD 3 CE- y reconvierten el TPC.c. (Título Preliminar del Código Civil) en un desarrollo normativo cuasiconstitucional de las garantías de la seguridad jurídica. La ficción de postconstitucionalidad aloja ese pasaje en un bloque cuya indivisibilidad, que refuerza las aspiraciones del jurista, desvanece las brumas del miedo al vacío. De aquéel forman parte las normas postconstitucionales -resto del ordenamiento jurídico subsiguiente a la instalación de la 
legalidad fundamental- y las preconstitucionales que, expuestas al control catártico del constituyente, no pecan de inconstitucionalidad sobrevenida, pues no se oponen frontalmente -aunque, en algún que otro aspecto accidental, los erosionen- a los principios y preceptos constitucionales con los que van a convivir. La aceleración de su incesante retorno revive los aspectos más álgidos de la aventura del Derecho justo y aviva el propósito de localizarlos en el horizonte constitutivamente histórico de la razón práctica. Buenas dosis de imaginación y lucidez hacen falta para encarar los problemas que van a plantearse con este motivo.

\section{Significado de la 'ponderación de la equidad' en la aplicación de las normas de los sectores del ordenamiento jurídico que necesitan de semejante auxilio}

El deber de ponderar la equidad no queda al arbitrio de los aplicadores del Derecho objetivo ni depende de la naturaleza -rígida o flexible- de las normas jurídicas en que acontece su injerencia. Se predica de cuantas situaciones polémicas necesitan instintivamente de una intervención justificada por el papel que la equidad asume, administra y despliega. La premura de la operación es un requisito indispensable para que el Derecho objetivo -a punto de desencadenar sus consecuencias- devenga lo imprescindiblemente justo o se aproxime, cuando menos, al ideal de la justicia ambicionada. La desidia o demora en acusar recibo de este encargo es una de las dilaciones indebidas que el art.24.2 CE declara atentatorias contra el contenido esencial o núcleo invulnerable del derecho fundamental de todas las personas a la efectiva -un adjetivo cuya fecundidad se ha desvaído-tutela judicial de sus derechos subjetivos e intereses legítimos. El descuido y la laxitud métodológica provocan los males derivados de no verificar si la norma jurídica incluye las cuotas de equidad que, para preservar su justicia, deben adornarla, o de acoger una versión tibia de la deuda de justicia material cuya integridad no se ha cumplido. La omisión del previo esfuerzo de saneamiento equitativo impide considerar justas las soluciones de un problema jurídico concreto, aunque su impecabilidad formal dé la impresión de lo contrario. Es difícil localizar el acto omisivo por el que el intérprete -aparentemente fiel al sistema de fuentes del Derecho objetivo- sobrevuela, como si lo hiciera sobre ascuas, los espacios francos de una equidad que, por falta de conocimientos o de arrestos, se abstiene de apreciar y ponderar acto seguido. El art. 3.2 C.c. concibe el acceso a la equidad como la posesión de un reducto de sosiego y respiro, pues descansar es eliminar, barrer la incertidumbre -que retrasa el encuentro con la verdad liberadora- y, hecho esto, construir y enunciar las soluciones que sugiere su descubrimiento.

Sobran argumentos para demostrar lo grave y lesivo de unas omisiones ayunas de sensibilidad jurídica. La justicia huérfana de la previa pondera- 
ción de la equidad que ordena el art. 3.2 C.c. se aleja de un bien -el de la tempestividad-que se predica de su noción cabal e indiscutible. La justicia -como concepto sintético que ha sido y sigue siendo- apareja la nota de integridad, inseparable de su esencia si se imparte en tiempo razonable, y se pervierte cuando -olvidando la puntualidad de su administración- sus retardos originan perjuicios harto difíciles o imposibles de resarcir.

$\mathrm{El}$ art. 3.2 C.c. no es un frívolo anuncio de que lo equitativo está de moda -como ciertos agentes económicos y sujetos sociales sostienen al defender la excelencia del retorno a los valores morales que alaban con entusiasmo sospechoso- y sí una sosegada invitación a examinar los rasgos de la mediación equitativa, a escrutar sus aspectos polémicos y a esbozar su sistema de oportunidades. El art. 3.2 C.c. no se ciñe a avalar académicamente la recepción de la equidad y de la justicia material que, al inspirarla, le infunde lo mejor y más loable de sus contenidos. Como algún otro precepto del TPC.c., el art. 3.2 C.c. - destinado, por definición y enclave sistemático, a facilitar la aplicación del Derecho- abunda en términos que, lejos de ser meridianamente inteligibles, requieren una interpretación adicional que ilustre sus funciones esclarecedoras. Acaso sea único en los anales de la patología de la interpretación el dato de que una regla hermenéutica -cuya inequivocidad tiene que disolver las equivocidades de las normas de Derecho objetivo y dejar su inteligibilidad fuera de duda-incurra en uno de los vicios cuya corrección se le encomienda y haya de interpretarse para fijar, como sucede aquí, el sentido propio del giro capital del art. 3.2 C.c. El tiempo y el modo verbales del precepto exigen precisar si la norma aplicable -elástica o de Derecho estricto- se ajusta a la equidad, se desentiende de su peso específico o conculca alguna de sus expresiones. Importa igualmente distinguir lo que la voluntad originaria del legislador quiso afirmar -cuando la norma debatida entró en vigor- de lo que, al cabo de un tiempo elocuentemente transcurrido, la voluntad evolutiva de la ley quiere decir sobre el alcance del verbo «... ponderar...». La equidad de aquí y ahora obedece a los fundamentos que antaño sirvieron para salvar del naufragio la justicia conmutativa de los contratos de tracto sucesivo o dependientes de sucesos imprevisibles y futuros. Sin perjuicio de otros cometidos notables, el de ponderar preconiza la modernización del mensaje de las normas jurídicas que, en vista de las experiencias deparadas por el paso del tiempo, devienen patentemente injustas o tan solo conservan un componente de justicia empequeñecido o marginal.

Nadie ignora la paternidad personal y académica de la reforma que, además de las coexistentes con ella, supuso la novedad del art. 3.2 C.c. Este conocimiento explica por qué y cómo se da entrada a un concepto jurídico indeterminado que -plasmado en la actividad de ponderar- se singulariza por la flexibilidad, el espíritu de reto y la susceptibilidad de acepciones fundadas en la calidad y el atrevimiento del discurso que desencadena su examen.

Reiterando anteriores ideas, una postura radical defiende la inutilización equitativa de las normas jurídicas que -contraviniendo la equidad-merecen 
ese trato y ceden su lugar a las proposiciones que la recta razón y el buen sentido extraen del depósito de las reglas del orden natural. Otra actitud, más tenue, propugna la remodelación equitativa de las normas mediante los actos de aplicación que, suavizándolas, acomodan a dicho depósito las asperezas del precepto escrito, cuyo texto dulcificado respeta lo sustancial de su mensaje. Una tercera amplifica el adverbio «... expresamente...», de que usa el. 3.2 C.c. en pro de la aplicación pluridireccional de la equidad, y considera que, aun sin la venia textual de los legisladores, la equiparación del giro «... expresamente lo permita...» al giro «... no lo prohíba de modo inequívoco...» autoriza a dirimir equitativamente los problemas cuyo sensato enfoque lo aconseje. El descansar exclusivamente en la equidad designa la querencia o tentación que, confirmada por el vigente sistema constitucional, le asigna un papel arreglado a su celebridad de ahora y siempre. El permitir expresamente que las resoluciones judiciales gocen de semejante tratamiento se equipara -vista la relectura dúctil que, para revitalizar el art. 1.131 C.c., se hizo del adverbio de modo- a la de que el espíritu y finalidad de la ley no veden terminantemente acudir a ella para ocuparse de cuestiones que, lejos de rehusarla, claman por su balsámica asistencia.

$\mathrm{El}$ art. 3.2 C.c. reprocha las posturas de insensibilidad que eluden los compromisos adquiridos con la decisión de conflictos cuya naturaleza impone y no exime de recurrir a la equidad liberadora. El espíritu y la finalidad del art. 3.2 C.c., a los que fundamentalmente debe estarse, respaldan la tesis de que la aplicación cabal de la equidad tenga lugar, con preferencia, a través de los modos extrajudiciales de composición-conciliación, mediación y arbitraje-que, no por azar o veleidad, se denominan equivalentes jurisdiccionales o sustitutivos procesales. Se reiteran los reparos -subrayados insistentemente- de una judicialización indistinta de conflictos cuyas particularidades fisonómicas no facilitan la unánime acogida de dicha solución. Muchos de ellos no se resuelven satisfactoriamente con la fórmula de la efectiva tutela judicial que el art. 24.1 CE pone al alcance de todas las personas. La efectividad canonizada se asocia más a las garantías de la seguridad jurídica que al obsequio del valor superior de la justicia situado en el vértice piramidal del ordenamiento jurídico y acaparador de la libertad y la igualdad que preceden a los principios y preceptos de la legalidad fundamental y la legislación ordinaria.

\section{Proceso de apertura al robustecimiento y la expansión de las exigen- cias de condición equitativa}

El ímpetu de que la naturaleza de las cosas hace gala en punto a la equidad se acrecienta con las pautas de interpretación que, contextual y sistemáticamente, elevan a la segunda potencia la prosperidad del mensaje del art. 3.2 C.c. Abierto el ciclo constitucional, los arts. 1.1 y $9.2 \mathrm{CE}$ se inscri- 
ben en un contexto común y general que, para agilizar la aplicación del Derecho objetivo, se predica -junto con los contextos particulares y específicosde todos y cada uno de los sectores del ordenamiento jurídico. Como versión modernizante de uno de los elementos interpretativos que el art. 3.1 C.c. convierte en un concepto jurídico indeterminado elástico y extenso, lo relaciona y cooordina con el espíritu y la letra de la legalidad fundamental.

Los arts. 1.1 y 9.2 CE enfatizan la vocación a la equidad, porque esa es la misión del criterio interpretativo contextual. Su significación sistemática también tiene importancia, pues, a todas luces, el TPCE alberga el verdadero preámbulo de la $\mathrm{CE}$, en vez del que, debido a uno de los episodios transaccionales del consenso y contra la realidad histórica de su autoría, encabeza su texto y se cierra con la promesa escalofriante-ocurrencia de uno de sus padrinos ajeno a la paternidad de la ley fundamental- de erigir una sociedad democrática avanzada. Este adjetivo final solapaba una opción -la propia del marxismo- a la que la voluntad maleable del constituyente no pretendía reservar ninguna de posibilidades flexibles, aunque otra fuera la impresión extraída de su condescendencia semántica.

Del examen del art. 1.1 CE se colige que la contracción gramatical «... del...»-antepuesta a la mención del ordenamiento jurídico- descubre un nexo de adscripción o pertenencia -nada tangencial o difuso- a dicho ordenamiento de los valores superiores culminantes de la pirámide que los interioriza. El valor superior de la justicia figura en el seno de un ordenamiento del que es parte integrante. Una rotulación inconfundible, que confirma esa tesis, usa de uno de los criterios contextuales de interpretación de la legalidad fundamental. Cuando el art. 147.3 CE reitera, de pasada, el principio de unidad de la soberanía estatal, declara que el Estado reconocerá los EEA (Estatutos de Autonomía) como una parte integrante de su ordenamiento jurídico -pues el adjetivo posesivo empleado atañe al ordenamiento jurídico estatal citado en los arts. 1.1 y 9.1 CE- y no a sendos ordenamientos jurídicos de las CC. AA. El art. 147.3 CE, lejos de desvirtuar el reconocimiento que el art. 9.1 CE hace de la unidad y unicidad del ordenamiento jurídico estatal, descarta las tesis favorables a configurar los EEA como piezas extrañas a la totalidad de ese ordenamiento o centrifugadas de él. Otros son los entendimientos alternativos o testimoniales que emanan de los acontecimientos veleidosos, de la laxitud funcional del régimen de las instituciones y de los acuerdos políticos domésticos que, sorteando los imperativos constitucionales, apelan, con menos comedimiento que osadía, a las demandas sociales y al espíritu del pueblo. El art. 1.1 CE pudo emplear la contracción gramatical «... al...» y definir módicamente la justicia como un valor superior que, desde el exterior, acondiciona e inspira la evolución del ordenamiento jurídico, pero que se halla fuera de los confines de su positividad y su estructura, pues, como los arts. 1.2 y 117.1 CE vienen a decir, el Derecho objetivo es un producto deontológico de la voluntad del pueblo soberano. $\mathrm{Si}$ no lo hizo, el criterio gramatical de interpretación fuerza la presunción de un 
espíritu y finalidad propicios a la significación más ambiciosa que la contracción «... del...» puede adquirir. Cierto que el valor superior del pluralismo político permite usar de un lenguaje lo bastante sibilino para devaluar la orientación propugnada. Según esta, la justicia -síntesis de la igualdad y libertad anejas a su indivisibilidad e inseparables de su esencia- dista de ser un incentivo mortecino o una nebulosa envolvente que, sin saturar el ordenamiento jurídico, lo impregna o colorea. Para el funcionamiento regular del Estado de Derecho, no basta, si la justicia material brilla por su ausencia, la validez conferida por el positivismo a las acciones normativas de la legislación -que secunda los mandatos constitucionales o las pautas del decisionismo político- y a los mecanismos del Derecho derivado subconstitucional.

La diferencia impresiona, porque la jurisdicción -intérprete caracterizada de la civilización cuyas contradicciones le atrapan sin tregua ni clemencia- capta el volumen de las situaciones injustas que, con independencia de otros adelantos, generan el hecho globalizador y sus divagaciones osmóticas, tanto por la expansión de sus efectos negativos, cuanto por lo inviable de una contundente represión judicial. No es causal que los diversos frentes de la jurisdicción compartan, frente a las estrecheces de la metodología, la voluntad indeclinable de transformar el Derecho en justicia y no en otros productos de autenticidad discutible. Tampoco hay que olvidar las operaciones de publicidad que -aireadas por los medios de comunicación y potenciadas por la desinformación de la opinión pública- miden, con varas de longitud variable y arbitraria, la extensión y la intensidad de la injusticia que gravita sobre la indefensa humanidad. De ahí que esté servido el germen de la rebelión contra los resultados colaterales y funestos -que haberlos, los hayde ciertas intransigencias del positivismo legalista.

La invención de un Estado judicial de Derecho, amén de sagaz y pertinente, se relaciona con esta alentadora propensión. Tal es su consigna -central o de fondo- y no los desvaríos que le imputan los grupos sociales hostiles a la veracidad informativa, intencionados ignorantes sus contenidos conceptuales e históricos, y explotadores de un sensacionalismo incompatible con la rectitud de intención. La idea de un Estado judicial de Derecho es, además de una ocurrencia afortunada, la confesión, a voces, de que algo se está moviendo o quiere moverse en estos pagos. Las decisiones de transformación pertenecen al signo de los tiempos y engrandecen la labor de aplicación de las normas jurídicas. La noción de justicia material conecta con el sentido propio de la contracción ortográfica -formada por la preposición «... de...» y el artículo determinado «...el...»- que introduce el art. 1.1 CE. La justicia se superpone, como pirámide menor, a la base superior del tronco de pirámide en que la imaginación geométrica del normativismo jerarquiza y apoya el sistema del Derecho objetivo. La lectura del art. 1.1 CE tiene de impresionante y novedoso el que no sea el texto constitucional y sí el concepto de justicia sustancial, intuida y ansiada por todos, el que, dentro del ordenamiento jurídico y no fuera de su continencia, reconquista la posición 
más encumbrada. La legalidad fundamental no es entonces la norma suprema y adquiere un rango dependiente de la jerarquía que impone la lectura no encogida e intrépida del art.1.1 CE. Quizás convenga releer el art. 5.1 LOPJ y hacerle decir que -allí donde proclama la supremacía de la carta política y calla sobre las preferencias del imperio de la justicia material- el haz o conjunto de normas supremas del ordenamiento jurídico reside en las pautas que el valor superior de esa justicia absorbe y dota de la posición eminente que el art. 1.1 CE le adjudica. Con otras palabras, las operaciones de factura constitucional y de legislación en sentido material o vertical, lejos de presumirse justas, se someten, de entrada, a los controles ejercidos en nombre de la justicia material y de la equidad que de ella está fluyendo. Conclusión suficientemente incitante para que -gracias al aliciente de su discurso inspirador- se oponga a cuantos, tachándola de hipermoralista, la rechazan y arguyen que el Derecho -rebajado al nivel de una disciplina doméstica- no puede erigirse en el máximo ético de las sociedades regidas por su acervo de normas jurídicas. La entereza vital del Derecho objetivo requiere algo más que una observancia minuciosa de las reglas formales a que su validez se subordina. Hay que determinar, antes de todo, si son justas las normas dictadas por los poderes públicos competentes para generarlas y transferirlas a un ordenamiento jurídico que, de otro modo, no está en disposición de hacerlas suyas. Arropado por este cuerpo de doctrina, el art. 3.2 C.c. enaltece la significación de la equidad y cobra una importancia que, como antecedente histórico, le asocia al más combativo de los entendimientos que -durante el cambio de las circunstancias de tiempo y de lugar de las realidades sociales- propugnan los arts. 1.1 y 9.2 CE. El enunciado de los valores superiores del ordenamiento jurídico resalta la justicia material, género próximo de las dos especies - a saber, la libertad y la igualdad-que comparten la subespecie del pluralismo político.

$\mathrm{El}$ art 9.2 CE abunda en excelencias. Exalta la justicia -que confirma o condena los estados de cosas derivados de producir y aplicar las normas jurídicas- como el compendio de la igualdad y la libertad que hacen de ella el óptimo instrumento de censura de la conducta de los seres humanos. Apunta las predicciones de la cláusula transformadora y social que previene contra la indiferencia de las comunidades indecisas o temerosas de dar pasos al frente en busca de su liberación. Impulsa, sin reducciones que la desfiguren ni asomos de tibieza que la debiliten, la voluntad y el espíritu de cambio de las operaciones indicadas, en general, y de las que, en peripecias más modestas, responden al reto equitativo del art. 3.2 C.c. El mensaje del art. 9.2 CE enseña que la libertad y la igualdad reales y efectivas -anverso de las libertades e igualdades falsificadas y rituales-acreditan las funciones sociales de la justicia material como causa eficiente de las transformaciones ocurridas allí donde su presencia se echa en falta y merece una ardorosa reivindicación. Son patentes las dosis de ilusión y de confianza que la línea de fuerza de este pensamiento transmite a la invocación existencial de la equidad. 
La efectividad propiamente dicha implica un concepto jurídico indeterminado que, invitando a definiciones exactas, difiere de la efectividad disminuida que es parte del contenido esencial o núcleo invulnerable del derecho fundamental reconocido en el art. 24.1 CE. Sus más caracterizados intérpretes han dejado escapar la ocasión que los arts. 1.1 y 9.2 CE facilitan para incoar, a medio o largo plazo, los avances moralizadores inherentes al espíritu de transformación. Prefieren un entendimiento axiológicamente mitigado y menos incisivo que el de una tutela judicial potenciada por el privilegio equitativo - una oportunidad de oro- de dichos preceptos.

Conviene añadir algo sobre la elevación de las garantías jurisdiccionales -comúnmente objeto de la legislación ordinaria- al rango de la efectiva tutela judicial y su enclave en la sec.1. ${ }^{\mathrm{a}}$, cap. $2 .^{\circ}$, tít. I CE, bajo el rótulo De los derechos fundamentales y de las libertades públicas. La efectividad del Derecho -dependiente del contenido de justicia material que la equidad otorga- difunde, gracias a la asistencia contextual de los arts. 1.1 y $9.2 \mathrm{CE}$, algo más enjundioso que la eficacia jurídico-formal de las resoluciones fabricadas al uso silogístico. La diferencia entre eficacia y efectividad implica que el segundo de ambos sustantivos no se predique de los arts. 1.1. y 9.2 CE con la misma fuerza que, según el art. 24.1 CE, lo haría de la tutela judicial reconocida en favor de todas las personas. La efectividad de la tutela judicial asegura la emisión de una respuesta cuyos fundamentos -convincentes y ajenos a las alergias del pensamiento débil-diluciden, con recia determinación de que la justicia material impere, las cuestiones de fondo traídas a debate. El potencial de los arts. 1.1 y 9.2 CE exige algo más propio de un Derecho que, según lo enfático de sus proposiciones, promete asimilar y garantiza una muy respetable, ya que no abrumadora, contribución de ese valor. La efectividad disminuida mejora el derecho a obtener la prestación de justicia que anuncia el art. 24.1 CE y aporta unos progresos tasados por su comedimiento conceptual. La efectividad plena y capital -divisada desde el observatorio de los arts. 1.1 y 9.2 CE- es una conversión del Derecho en justicia que, además de esclarecer el sentido de las normas incomprensibles o confusas, toma cuenta y razón de las contradicciones sociales que aquejan a los aplicadores de aquel en el medio donde realizan sus operaciones, se cerciora de los imponderables que alteran su equilibrio y esclarece los desafios de la civilización que, como agente significativo de sus cambios y/o espectador crítico de sus incidencias, le ha tocado en suerte protagonizar. La efectividad designa el volumen digno, justo, equitativo y saludable de un Derecho ligado a criterios que, con la vista puesta en los arts. 1.1, 9.2 CE y 3.2 C.c., no nacen de ligerezas teorizantes o frivolidades de ocasión, y sí de unas valoraciones que -aunque polémicas, como cuantas atañen a los temas del mundo del espíritu- merecen el crédito debido a la calidad técnico-jurídica, la insistencia y la oportunidad de sus ofrecimientos.

$\mathrm{El}$ art. 9.2 CE -que hizo circular esta idea- se comprende en función del precedente que representaba el art. 3 II CE y de la inspiración -aquí acepta- 
ble-del pensamiento jurídico soviético, cuya doctrina fue la de que, por obra y gracia de un aviamiento peculiar, el Derecho se estaba preparando para algo más que armonizar, bajo el consabido imperio de la ley, las disidencias de las personas y/o los grupos sociales. Le incumbía el papel de motor o agente de las transfiguraciones que -impulsadas por una opinión pública verazmente informada y ávida de concretar sus entusiasmos- esperaban las sociedades prestas a reemplazar los inmovilismos asfixiantes por la novedad y la fertilidad de otros hallazgos tentadores.

Reiterando que ninguna cosa puede ser y dejar de ser al mismo tiempo, el principio ontológico de no contradicción ayuda a perfilar el concepto jurídico indeterminado de efectividad. No se trata de una noción de laxitud desconcertante, ayuna del método que su flexibilidad aconseja para salvar los escollos de su definición o superar las dificultades conexas, y a la que se atribuye un dinamismo que, oscureciendo y/o fraccionando su atormentado entendimiento, produce consecuencias de transformacion. Los arts. 1.1 y 9.2 CE propician el entendimiento maximalista de la efectividad en un terreno donde, vencidos los obstáculos y desarmado su cuerpo de objeciones, el empuje de lo equitativo -testimonio, por antonomasia, de la justicia material- gana las batallas libradas contra algunos anacronismos de que el positivismo legalista no ha conseguido liberarse. Otro modo más doméstico y tenue de entender la efectividad depende de una comprensión minimalista y asociada a la lectura que -sin plantear los problemas de la justicia materialse hace del art. 24.1 CE, cuando se da por buena la emisión de una sentencia que, sin escudarse en reparos formales y encarando la cuestión sustantiva pendiente, muestra la fuerza persuasiva -seductora de los entendimientos y las voluntades sensibles a su raciocinio- de los fundamentos jurídicos del fallo recaído. Cae de su peso que, en cuanto renovadora y ambiciosa, constituye aquella la doctrina elegible para disolver -aunque no se haya impuesto oficialmente- la antinomia interpretativa. Representa el triunfo de una corriente aplaudida por el sentimiento popular que mantiene la confianza puesta en sus alentadoras perspectivas.

No son vanas las divagaciones que se siguen de esta distinción. Las líneas de fuerza de aplicación del Derecho objetivo señalan, si lo imponen su aliciente y originalidad, los caminos útiles para encarrilarlas, analizan las demandas de la conciencia común e invitan a frecuentar un discurso cuya energía razonable detiene las acritudes críticas, cercena las censuras malintencionadas y denuncia su extravío intelectual. Se respaldan dogmáticamente, se actualizan y se multiplican los auxilios técnico-jurídicos en que -a través de una ponderación exahustiva- las directrices del orden natural de la equidad resuelven, de modo tangiblemente justo, controversias en que se cumplen unas operaciones de reemplazo. Consisten estas en sustituir por remedios extrajudiciales los tratamientos jurisdiccionales que, ante conflictos de nueva factura, producen resultados deprimentes, no por insuficiencias naturales y sí por carecerse de instrumentos aptos para facilitar la asistencia 
esperada y exigible. La protección judicial acorde con la naturaleza de las cosas requiere medios personales y reales de los que, ni hoy ni a medio plazo, se dispone para caldear la versión tibia que encierra la interpretación preponderante del art. 24.1 CE. Llegada la oportunidad de apostar por esos adelantos, se aprecian las dificultades que aquejan al grueso de sus eventuales especies y a la unanimidad de su acogida.

La equidad amortigua las inclemencias del Derecho Positivo si las acciones u omisiones del legislador -debidas a reducciones simplificadoras o a previsiones inexactas- no acreditan los mínimos de justicia precisos para dilucidar las controversias individuales y colectivas a cuya solución se destinan. La tarea no se satisface mejorando la gestión ordinaria de los intereses en pugna y deja de ser tal si no encara el dilema de sobrevivir o perecer. El orden natural de la equidad marca el paso y contribuye a zanjar los conflictos cuya pacificación depende, al menos, de dos condiciones. Una, el progreso general y los avances especiales que provienen de los esfuerzos de transformación. Otra, el tesón de los juristas resueltos a lograr que, a causa de la detestación universal de la injusticia, su derrota se adivine como algo que, si se quiere en cuerpo y alma, casi se está tocando con las manos.

\section{Particularidades que ofrecen la generalización del Derecho objetivo y el retorno a las posiciones de inspiración equitativa}

La invocación de las normas que nunca saturan, porque su devenir es incesante, el depósito del orden natural de la equidad, se refiere a los conflictos que admiten soluciones compatibles con las directrices de la justicia material. Conciernen a materias sustraídas a las prohibiciones del Derecho necesario -comprensivo del orden público textual o virtual- y dependientes de la autonomía de los interesados que, libres de impedimentos o coerciones, disponen válidamente de sus bienes y derechos. Se recuerdan de nuevo las consideraciones que, ante esa posibilidad, aluden al diseño de un ordenamiento jurídico que el art. 1.1 CE erige y patrocina sugestivamente. Este avance -que arrincona los calcos, típicos y tópicos, del normativismo- abre rutas cuyas dificultades y atracciones les distinguen de los vulgares caminos trillados, porque su venturoso recorrido compensa, con creces, los desvelos del tránsito. Se reprocha lo inflexible de las posiciones entregadas a canonizar la generalidad del Derecho en las nuevas circunstancias del tiempo y del lugar que -aconsejando la aplicación morigerada de sus normas o admitiendo las razonables excepciones que su mejora exige- cuestionan aspectos existenciales de su funcionamiento.

El espíritu móvil de ese pensamiento no casa con la idea -irrenunciable para normalizar el juego de las instituciones del Estado social y democrático de Derecho- de que la justicia material y la seguridad jurídica se coordinan mediante un sistema de vasos comunicantes que aligera las tensiones 
internas del ordenamiento jurídico. La voluntad de transformar se traduce en el énfasis con que, al subrayar la elección libérrima de las iniciativas del decisionismo político, el art.9.2 CE veda las regresiones de corte antisocial. Desenmascara la falsa mesura que -ayuna del arrojo inteligente y hostil a cualesquiera desvaríos- coarta las posibilidades de una actualización equitativa y responsable. Transformar es desigualar materialmente-liquidando la complacencia y el escándalo de los desequilibrios injustos-para que los valores de la justicia sustancial y sus testimonios de equidad conquisten los espacios en que las demandas sociales depositan la esperanza de tutela de sus intereses. Ahí se dan cita los clamores -tácitos o explícitos- de cuantos, integrados en las comunidades de la sociedad pluralista, difunden las reivindicaciones de una opinión pública que abriga el más firme propósito de sumergirse en el fondo de las cosas y defender los valores explícitos en la certeza de su conocimiento.

$\mathrm{El}$ art. 9.3 CE no relega al olvido la seguridad jurídica, aunque sorprenda la modestia -resarcida con su enclave sistemático en el TPCE- del tratamiento que impide atribuirle el carácter de derecho fundamental o garantía equivalente de la sec. $1 .^{\text {a }}$, cap. $2 .^{\circ}$, tít. I CE. Dicha seguridad muestra una fortaleza de proporciones medias que, preservando su intangibilidad conceptual, invita a revisar las reservas y/o las verdades incompletas que, invocándola rudimentariamente, desdibujan sus inflexiones y matices. La consigna que dice preferir la injusticia al desorden tiene la oportunidad -históricamente irrepetible- de sucumbir al aliciente de una proposición provocativa que rece como sigue: Hay que observar, en actitud de vigilancia permanente, los cambios del orden positivo que, tras elogiar lo impecable de las normas jurídicas y concebirlas como dechados de armonía, se confunden, llegado el momento, con el desfallecimiento de un Derecho vigente que, sin pecar de imprecisión ni proponerse causar agravio alguno, resulta anquilosado o residual, pues entorpece las actividades necesarias para que la justicia material y la equidad se reinstalen en sus paraísos perdidos y recobren las que, siempre y en todo lugar, debieron ser sus zonas inalienables de influencia. He aquí el imperativo categórico de una actitud disciplinar que, atreviéndose a pensar por desinteresado amor a la verdad, sugiere el arte de arrostrar los desafíos que el nuevo milenio dirige a una humanidad obligada a sanar las miserias de sus más indigentes pobladores. Esta conmoción o escena revolucionaria encarna la esperanza de la razón sin historia que, al contrario de la contrarrevolución o historia sin razón, nace de un pensamiento jurídico doliente y conminado a un implacable examen de conciencia. Quiere desvanecer las confusiones de la oscura desbandada que corre riesgos inversamente proporcionales a los méritos de quienes los padecen. Es uno de ellos el de que -no ya dos veces, sino por tiempo indefinido- la humanidad tropiece con la misma piedra, sufriendo los efectos de sus alergias antirreflexivas y las asfixias de sus peticiones de aire libre. El orden natural de la equidad cumple el papel que -para moderar o impedir esos 
males- dicta una metodología de la transfiguración que promete, gratifica, reconstruye e innova con el más ferviente de los entusiasmos.

La graduación de las predilecciones por los medios, modos y formas de la aplicación equitativa del Derecho parte de una premisa que, irrumpiendo entre las luces y las sombras de su modernidad, se adueña de las potencias del alma. Cunde la convicción -debida al grosor de las identidades y la diversidad de los conflictos- de que, con independencia de su tenor favorable o adverso, muchas soluciones derivadas de aplicar las normas jurídicas de carácter general defraudan o perjudican a terceros que, además de las partes, se sumergen, como interesados y sin participar en la contienda, en la extensión de las relaciones procesales que a la sazón se constituyen. Cabe añadir un toque de equidad voluntariosa, que, impregnando los fundamentos de Derecho aducidos, cuide de velar por los intereses en juego -difusos o indirectos-y las situaciones tangenciales que les acompañan. Las tesis pulquérrimas de la plenitud del ordenamiento jurídico y de la impecabilidad estructural del sistema de fuentes del Derecho objetivo no siempre ayudan a colmar la saciedad prometida por una de las bienaventuranzas evangélicas a quienes tienen hambre y sed de justicia.

Una estadística veraz da fe de estas carencias y de las frustraciones que las acompañan. Hay conflictos de semblanza coincidente o afín, cuya disección permite alzar el velo y exhumar los caracteres de su fisonomía. Presentan matices conceptuales o históricos que, disipando cualquier semejanza, impiden elegir una norma jurídica supuestamente aplicable a todos ellos. El tratamiento uniforme de estos casos -lejos no ya de asegurar, sino de aproximarse a los dictados de la justicia material- entorpece su satisfacción, porque repara en aspectos que, al comprobarse la diversidad, impiden apreciar -porque nunca existieron- la equivalencia o la igualdad que precipitadamente se prejuzgan. El recurso a las normas del orden natural de la equidad garantiza -junto con los mínimos de la justicia material que se espera y exige- la fiabilidad de unos criterios cuyo esmero individualizador purga la rigidez de soluciones toscas o menos reflexivas.

Así sucede con las que, adaptando fatigosamente sus pautas, cumplen las exigencias objetivas de sometimiento exclusivo al imperio de la ley y de respeto al sistema de fuentes, como disponen los arts 1.1 y 9 C.c., y $117.1 \mathrm{CE}$, aunque su inflexibilidad también alcance al interés común de operaciones -sociales, económicas o de pareja envergadura- afectadas por las advertencias secundarias que, durante su desarrollo, derivan de las objeciones o los razonables cambios de criterio de uno o varios de sus ejecutores. Al paralizarse el curso de aquellas con perjuicio para su reanudación inmediata, se atiende a lo menos en detrimento de lo más. Solo la intervención de la equidad -que oportunamente comparece-cura el mal de esas interrupciones y evita ir en busca de un tiempo perdido que, a decir verdad, no siempre se recobra y acaba pasando gravosas facturas. 


\section{Reiteración cíclica de los episodios históricos en que se localizan las reacciones de llamamiento y restauración de la equidad}

Alecciona el examen de las fases -mejor o peor diferenciadas- que muestran la propensión alternativa a exaltar, de una parte, los valores sociales de la generalización lisa y llana de las normas de Derecho objetivo y a defender, de otra, las ventajas de su aplicación equitativa. La conciencia jurídica estabilizada - por algún tiempo, al menos- aplaude esta segunda opción e invita a divulgarla mediante la efectividad de un Derecho cuya conversión en justicia constituye el norte de sus propósitos de transformación.

La factura técnica del Derecho seleccionó los modelos de promoción equitativa que -al especificarse las acciones judiciales del caso y sancionarse la autoridad moral y jurídica de sus ingredientes sustantivos- amparaba los apetitos por los bienes sensibles de la vida que, mientras no dispusieron de ese contrafuerte, eran solo intereses desnudos. Su aceptación social -a título de intereses vestidos- les añadió el plus protector de la exigibilidad judicial y extrajudicial con que la Ciencia de la Legislación premiaba sus merecimientos. La multiplicación de estas ofertas sedujo al Derecho general o común y dejó atrás el casuismo de los episodios que asociaban el Derecho vivido a la evanescencia de las decisiones judiciales que le declaraban. Los fenómenos de las recepciones -importación de elementos contribuyentes a la perfección de los sistemas- se debieron a estímulos generalizadores que reafirmaban sus principales objetivos. Se actualizaban las bases de un Derecho común que, reteniendo los particularismos coherentes, aceleraba el progreso de las comunidades que se beneficiaban de esos cambios.

La reiteración experimental volvió a sugerir las actitudes jurídicas flexibles que chocaban con el antecedente de una generalización voluptuosa del Derecho y denunciaban sus fragilidades. La novedad del libre examen y el advenimiento del espíritu crítico -claves de la instauración del humanismose enfrentaron a lo presumiblemente irreprochable de las soluciones generales. El absolutismo del poder político agrietó estos valores y reemplazó sus trazos intelectualistas por el voluntarismo de otros que -fieles a la tesis de que lo bueno era tal en virtud la autoridad que dictaba sus mandatos y prohibiciones- acomodaban el tratamiento de las controversias a sus conveniencias fisonómicas. Se apostó por la utilidad de un Derecho que, despidiéndose de una generalidad incómoda, brotaba -sin interferencias ni apremios de agentes extraños- de la decisión del soberano y del título de legislador incorregible e impecable que le atribuía la teoría del origen divino del poder político. La emergencia de las relaciones internacionales mercantiles, la prosperidad de los descubrimientos, la dominación competitiva de los nuevos espacios geográficos -terrestres y marítimos- y la mundialización a escala de entonces de las realidades histórico-políticas, fueron los factores de asombro que reabrieron las reflexiones instintivas de la filosofía. Liquidaron los desencantos de la melancolía -debidos al fracaso de la curiosidad cuya 
intrepidez no disipa lo tenebroso del misterio- y celebraron las victorias que, al probar la buena fortuna del cambio, confirmaban la excelencia que se le suponía. La proliferación de estas variantes invitaba a un estilo de vivir desenfadado y pluralista, que armonizaba las soluciones generales con las orientaciones de equidad.

Se abre luego la zanja entre el Derecho general y culto -confinado en la enseñanza y el aprendizaje universitarios- y el Derecho equitativo que, ceñido al ámbito de los Derechos locales, proporciona soluciones erráticas, fruto de la vulgaridad y la inesciencia. Esa equidad -casuística y rudimentariaera obra de unos juristas prácticos, deficientemente educados en Derecho e ineptos para desarrollar, con un mínimo de ilustración y esteticismo, el discurso jurídico que debían dar a conocer. Deslumbrando los entendimientos y ganando terreno al margen de la práctica, la enseñanza universitaria divulgaba los postulados del orden natural realista que, alejándose de la tradición idealista, defendian la eminencia de los principios universales del Derecho -continentes y germen de los derechos subjetivos innatos- y la posibilidad de que, sin auxilios sobrenaturales que iluminasen sus ámbitos opacos, la razón humana llegase a conocerlos. Todo ello, según las afirmaciones arrogantes de los mentores del iusnaturalismo secular. Guiados por esta orientación y renovando el objetivo de la generalidad de sus líneas de fuerza, los codificadores contribuyeron a edificar el Derecho Positivo con propuestas cuyo academicismo excelente debía fulminar las objeciones de inseguridad y dispersión en que abundaba aquel casuismo. Pese al impacto de este compromiso y al paso adelante -salto cualitativo de hoy día- que representaba, los principios de incondicional aceptación y de acogida universal dejaron de serlo y, al cabo de algún tiempo, retornaron a sus cuarteles de invierno. El espiritu del pueblo -vencido en la batalla que había enfrentado a los adeptos y a los adversarios de la codificación- no renunciaba a tomarse, más pronto que tarde, la revancha. Un desquite apoyado por las vehementes adhesiones que -defendiendo el derecho de toda Nación a convertirse en Estado independiente- despertaba el principio de las nacionalidades.

La recepción del principio de las nacionalidades relegó a un plano secundario las afinidades de los pueblos y primó las reivindicaciones de la conciencia y el sentimiento de la identidad sobre los compromisos contraídos con la causa del ecumenismo del Derecho. Los pueblos respetaron el culto a los valores del Derecho universal, aunque, aliviando estas inclinaciones, defendieron la idiosincrasia de las comunidades orgullosas de haber dejado a salvo su espíritu de creatividad jurídica para ejecutar el proyecto sugestivo de vida en común que sus habitantes anhelaban. La multiplicación de las constituciones burguesas que, rebajando los niveles del iusnaturalismo secular, restringieron sus incertidumbres y aportaron elementos de certeza jurídica, favoreció la reposición de las identidades históricas y el resurgimiento de las tradiciones cuya puesta al día realzaba esas especialidades. El 
nuevo rumbo reactivó la polémica sobre la petrificación o la elasticidad de los principios que cooperaban a encauzar la marcha de los procesos codificadores conforme a los signos de los tiempos. El Derecho universal pasó a serlo menos y los Derechos nacionales invadieron los dominios de la modernidad para acreditar su sensibilidad a lo evidente de los cambios. Se desvanecieron las ilusiones y esperanzas puestas en rescatar las ventajas de un Derecho común-indefectible y expansivo-cuyos intelectos pensantes mudaban el emplazamiento de las que habían sido sus posiciones de vanguardia.

Los sucesivos testimonios históricos prueban la terquedad de estas inclinaciones binómicas. Recuérdese cómo -tras una de las más denigrantes servidumbres que escarnecieron a la familia humana- la tarea de configurar la Europa moderna incluía la asignatura pendiente de rehacer, con una buena cuota de imaginación cooperativa, un novísimo Derecho común que comprendiese el Derecho fundamental o primario y el Derecho derivado o secundario. El primero ejemplificaba la llamada paradoja comunitaria que apelaba a la técnica de los Tratados Internacionales para ejercitar el poder constituyente, como, además de anteriores ensayos, lo prueba la aflicción con que, apenas dada la señal de salida y salvando los muebles con algún decoro, el TL (Tratado de Lisboa de 13 de diciembre de 2007) quiere ocultar el fracaso de la frustrada Constitución para Europa. El segundo abarca la llamada legislación en sentido material o vertical, conjunto de normas subconstitucionales que aseguran la plenitud del ordenamiento jurídico. La tentativa de reinventar ese Derecho común no es un modelo de coherencia ni se puede jactar de haber alcanzado un éxito espectacular a favor de la causa de la justicia material. Tropieza con la resistencia de los países miembros a trasponer las Directivas comunitarias e injertarlas en los sistemas nacionales. Acusa las dificultades técnico-jurídicas de aplicar inmediatamente las Directivas que, pendientes de trasposición, soportan la hostilidad o la apatía de las voluntades políticas de los Estados miembros. Sucumbe al albedrío de las jurisdicciones nacionales que, salvo en los casos de alegación relevante del Derecho Comunitario europeo aplicable o del planteamiento de cuestiones prejudiciales, acuden, sin mala conciencia, al depósito de la legislación interior. Como si el principio de primacía del Derecho Comunitario -eventualmente conculcado- se redujese a un elemento ornamental del contexto jurídico de la Europa que solemnemente se declara unida y presta a la igualación en el progreso, aunque -a la vista de los hechos- se multipliquen los recelos sobre la sinceridad de estas alocuciones y la efectividad de sus promesas. ¿Dónde están, por citar un ejemplo de importancia máxima, los testimonios convincentes en lugar de los alegatos baldíos sobre la tierra prometida de la Europa social? Muchos encuentros académicos han coincidido en censurar la frecuencia con que a las normas de aquel ordenamiento jurídico se sobreponen las de los Derechos nacionales que, depreciando el valor de las cuestiones debatidas, confieren al Derecho común un carácter olvidadizo o residual. 
Los duelos y quebrantos de la tendencia universal a aplicar el Derecho objetivo provocan muchos desalientos. Decepcionan los cambios de rumbo de las ofertas hechas a la sociedad que espera del Derecho la salvación de sus incidencias conflictivas, pues confía en lo inmediato y justo de su solicitud, siendo así que la generalidad de las leyes se compendia, cuando menos, en dos proposiciones. Según una de ellas, la norma jurídica -cuya acertada elección permite encajar la pequeña historia del problema en el supuesto de hecho que le corresponde- no puede resentirse de holguras que, aunque formalmente se remedian con la plenitud del sistema de fuentes del Derecho objetivo, obstan a los imperativos de la justicia material. Conforme a la otra, las normas jurídicas no pueden ser pan para hoy y hambre para mañana y ha de evitarse que su anquilosamiento frustre la función transformadora del criterio finalista de interpretación y de las correcciones cuasilegislativas que sus aplicaciones representan. Los auxilios del orden natural de la equidad favorecen la subsistencia de estos requisitos y recuerdan la necesidad de tenerlos en cuenta.

Los problemas jurídicos surgen, se modifican y se enturbian en los más alejados pagos de la Tierra que -aunque achicada por la globalización-cuenta con espacios bastantes para organizar operaciones de gran cabotaje. La consideración tardía o poco equitativa de sus pormenores puede esterilizar sus objetivos y enfrentar, hasta el punto de aniquilar sus ventajas, las voluntades que los coasumieron. Sus soluciones interlocutorias deben ser -no huelga repetirlo- equitativamente justas, para afianzar los resultados del proyecto en curso, a la vez que accesibles y rápidas, para no romper los lazos de solidaridad que han de mediar entre quienes, resueltos a cumplir ese empeño, confían en su conclusión satisfactoria.

\section{3. ¿Cómo se adviene al 'sentimiento de equidad' y se sientan los funda- mentos exigibles para edificar el 'Derecho justo' que emana de su conocimiento y puesta en posesión?}

Es de notar -en cuanto concienzudamente valorado y harto difundidoel paralelismo apreciable entre la noción de virtud o fuerza moral y la idea de disponibilidad equitativa. Ahí resuenan los ecos inefables de una sabiduría cuyos mensajes -pendientes de transmitirse o completarse- postulan incondicionales adhesiones. Esa sabiduría -inseparable de la posesión de la equidad y de su vasto repertorio de auxilios- necesita ser devotamente comprendida por cuantos asocian sus preferencias éticas al ejercicio de la solidaridad. Su control de calidad depende de las iniciativas que las enriquecen, del culto rendido a la sensibilidad moral y del peso específico de su bondad y su eficacia.

Las reacciones equitativas se arreglan a lo que, según las impresiones causantes y/o provocadoras de su escenificación, trasluce el orden de la 
naturaleza. Proscriben lo que, perdiendo el respeto a su armonía, lo contradice o arrincona. El haz de adquisiciones que mejoran la sensibilidad equitativa alimenta un depósito situado en el interior de la persona que, cautiva de sus alicientes, sucumbe a lo admirable de esas innovaciones. La vida personal se torna envidiablemente equitativa cuando el entendimiento -apegado a la virtud moral que lo aprisiona en el mejor de los sentidos- construye planes de acción y/o pensamiento que, sin variar los dictados de la recta razón, destina al uso propio. Son exigencias a las que el individuo -consciente de la necesidad de acatarlas- adapta sus formas de conducta y a las que, por obra de una dependencia duradera y estable, vincula el compromiso de actuar equitativamente.

La conciencia estática y la razón dinámica puntualizan las soluciones de equidad. Comparten los modos de escrutar y decidir, aunque difieren en sensibilidad intuitiva, dotes de improvisación y plasticidad de sus operaciones. Codiagnostican la justicia material de las situaciones que analizan y valoran la urgencia de los experimentos que su toma de contacto impone. La vocación equitativa del sujeto -propulsor de la empresa emblemática de difusión del bien- descansa en las adquisiciones de su talante individual, revela un ingrediente esencial de su siquismo, transparenta sus tensiones morales y precede a las reflexiones del discurso, aunque, para calmar muchas de sus perplejidades, también llama en su auxilio a la razón. Los proyectos, las perspectivas y los comportamientos eficientes -servidos por las personas y los grupos sociales de imagen más variada- se inscriben en los marcos de la acción y la pasión equitativas. Se exploran y concretan gracias a las reacciones que los imperativos de lo justo fecundan en los más íntimos reductos de la conciencia individual.

Conviene estudiar el papel que cumple la razón cuando intenta captar el sentimiento equitativo y enterarse de las oportunidades que su noticia le depara.

La razón humana contempla las variantes de objetividad o ausencias de vacío que despiertan la devoción, la indiferencia o el rechazo consecuentes con las actitudes de asombro que provoca su conocimiento. Sus acciones se acercan a un estado de cosas que, ocupando lugar, acampa en los espacios etéreos del mundo del espíritu -donde el entendimiento percibe y medita- o en las zonas tangibles de la naturaleza, donde es central la comprobación exacta de lo verdadero y de lo falso. Aborda realidades que -sensorialmente o acompañadas de la lógica- suscitan cuestiones solubles con el empleo de un discreto esfuerzo o refractarias a la aprehensión de su sustancia y su inventario de valores. Cuestiones que, en razón de estos datos, soportan el juicio general, las vacilaciones, la descalificación o los elogios de quienes se encargan de sistematizarlas con delicadeza inseparable del amor a la verdad. Se logra así la información veraz que -más allá de las verosimilitudes eventuales - facilita los conocimientos y las oportunidades de opinar. 
La razón humana es también la aptitud -gobernada por la voluntad de los sujetos portadores- de adjudicar al todo o a una parte de la realidad, cuyas transformaciones excitan la curiosidad y galvanizan el asombro, una identidad por la que inequívocamente es igual a sí misma, y no algo semejante que, ocultando sus diferencias específicas, crea el riesgo de confundirse con ella.

La razón difunde -a causa de su presumible excelencia- o publica -gracias a lo singular de sus perfiles- la realidad directamente percibida, que llega a su conocimiento, y el discurso que, al desentrañarla, explica las transformaciones que se propone esclarecer. Hay una transferencia de la zona del concepto o la representación inteligible -consecuencia de analizar la realidad- a los dominios de la cualidad o símbolo traducido en el término de la representación conceptual que se consigue. El lenguaje elige y canoniza los términos para comunicar lo que es y lo que representa. Reseña sus dimensiones ontológicas y anuncia la suerte que se les reserva. Tal es el mínimo de los instrumentos pedagógicos transmitidos a los destinatarios del mensaje final que les ilustra.

El ciclo del devenir de la razón abarca las ocurrencias interpuestas entre el alfa y el omega de sus episodios. Evoluciona -relacionando los conceptos cuya interpenetración términológica elabora los juicios sobre las situaciones afectadas- y adviene, mediante proposiciones intermedias, a las conclusiones que cierran su discurso. Se pretende que -atreviéndose a pensar para conocer por cuenta propia y definir verazmente los frutos de ese comprometido pensamiento- los más de los entendimientos asimilen, sin recortes básicos ni errores de bulto, los mensajes destinados a criticar-refrendándolas o disintiendo de ellas- unas ideas que se aceptan o rechazan. Son decisivas la intensidad y aun la pasión de las motivaciones con que los grupos de destinatarios expresan el cuanto de predilección o indiferencia que les merece la suerte de los intereses en juego. Las proposiciones -que alojan y hacen circular esos juicios- se dirigen a una razón humana que, para entrar en posesión de la verdad, se compromete a obrar en consecuencia. Hasta entonces, la razón se conduce acromáticamente, no por neutralidad o desgana intelectual, sino porque sus mortecinas luces solo de súbito se encienden al ponderar la grandeza y servidumbre de los retos que aguanta y, como reza la jerga deportiva, acusar las dolencias del miedo a ganar si responde a sus provocaciones.

Los ejercicios de la razón humana pueden extraviarla, confundirla, obcecarla o coaligarla con las fuerzas del mal. ¿Cómo y en qué medida sucede esto?

La razón humana se tilda de razón extraviada cuando la hondura de sus desvaríos revela que sus mecanismos, garantes de la sensatez de sus juicios, carecen de la dosis de rectitud propia de su ejercicio. Se trata de una razón tortuosa que atenta contra el sentido común -grado de madurez y de cordura impuesto a cuantos emprenden esas operaciones- o deriva en valoraciones aberrantes. También deambula una razón confusa, cuyo espacio habitable no 
es fácil de situar en el círculo de luces y sombras que, deformando o empalideciendo la verdad, la desfiguran indefectiblemente. Parece hallarse cerca de la idea de la verdad buscada, aunque -desdibujando sus perfiles y sin traicionarlos descaradamente- fracasa en el intento de mostrar su verdadero rostro y servirle con la lealtad que se merece. Se tropieza, otras veces, con la razón obnubilada y presta a negar las evidencias aclamadas por los entendimientos más lúcidos y las voluntades más rotundas. La esclaviza un pensamiento de deseo que -disfrazando sus errores de aciertos espectaculares y eludiendo las oportunidades de acción clarividente- desestabiliza la armonía que ha de reinar a ultranza entre el amor a la verdad y la destreza de los métodos aptos para dar con ella. Sin olvidar las aventuras de una razón maléfica, cuyo decisionismo -oculto tras rebuscadas apariencias de razonabilidad- descansa en prejuicios fundamentalistas y exentos de la objetividad precisa para reconciliar, si es del caso, las posturas de exterioridad irreductibles. Quizás haya -como conviene a la sustancia del mundo del espírituotras modalidades que, amén de las enumeradas, amplían el repertorio de las falsificaciones y secuestros del concepto de recta razón.

La recta razón -cuyo pulcro ejercicio depura y acredita la entrada en posesión de la equidad-invita a glosar la noción de lo que se entiende por belleza. Se transfiere a la idea de que es equitativo aquello cuyo conocimiento y comprensión reúnen los atractivos del deleite moral y la satisfacción intelectual. Así se afianza el equilibrio entre la concepción natural de lo bueno y la inclinación emocional que, en cada circunstancia, caracteriza al ascendiente del pensamiento equitativo y su conversión en norma jurídica. El dinamismo equitativo -consecuencia de una crítica acorde con los modos que la recta razón tiene que conocer- está en el campo de estas oportunidades.

La equidad se asocia a los modos de composición extrajudicial recomendables para agotar el cuanto de justicia sustancial que, bajo su advocación, quiere obtenerse. Su depósito consta de reglas debidas a la movilidad síquica de la razón recta y sujeta a las pautas de la justicia material que la informan, pues, al diagnosticar el estado de cosas que se le somete, no yerra y emite pronósticos cuyas persuasivas predicciones convencen socialmente de que son los más dignos de elegirse entre cuantos corresponden a las circunstancias del tiempo y del lugar en que el conflicto toma cuerpo y exige una pronta pacificación.

\section{Consideraciones sobre el significado y las oportunidades que hoy día ofrece la equidad para mitigar los antagonismos conflictivos y zan- jar los enfrentamientos que originan}

¿Cómo y por qué gana terreno el apego a usar de una equidad que elimine los males evitables con su contribución? Han decaído las ilusiones pues- 
tas -con resultados menos gratos que los esperados de sus predicciones eufóricas- en la efectividad o garantía de justicia material de un Derecho Positivo que antepuso el simplismo de la seguridad jurídica a las circunstancias equitativas del caso y no dio las facilidades que pudo y debió procurar para reconciliarlas. No se ha consolidado -cuando el diálogo entre las civilizaciones intenta, con fortuna improbable, templar las animosidades que exigen tratamientos menos ingenuos y más ingeniosos- un Derecho común, mundial o universal que reviva las ambiciones excitadas -histórica y dogmáticamente- por los fenómenos de las recepciones, incluidos los impactos codificadores. El fracaso de la denominada -tan académica como estérilmenteConstitución para Europa ha relanzado la paradoja del Derecho Comunitario y, en las angosturas de un callejón sin salida, ha urgido a abandonar el proceso constituyente -técnicamente adecuado a la naturaleza jurídica de la UE (Unión Europea)- y a emplear, en su lugar, los conceptos vicarios del Derecho Internacional Público a que apela de nuevo el TL. Los prejuicios y divisiones que frustran esa tentativa truncan las soluciones acordes con el orden natural y el criterio valioso de tantos juristas que, cargados de razón, capitulan ante otros poderes que escatiman la generosidad de la sabiduría necesaria para obrar en justicia. Son hostiles a la que se llamó funesta manía de disentir o de pensar y remisos a condenar las ofensivas que -ignórase a qué precio- el voluntarismo neoliberal fomenta contra una igualación en el progreso que, aunque solemnemente estampada en el art. 136 I VCTR (Versión Consolidada del Tratado de Roma de 25.05.(19)57, modificado por el Tratado de Amsterdam de 20.10.(19)97) apenas ha emprendido la escalada de las cimas del cambio.

El hambre y la sed de justicia -que laten en todos los rincones de la Tierra y agigantan los ecos de sus indigencias- explican la creciente invocación de la equidad, el estímulo de sus funciones sociales de transformación - para resarcir las situaciones quebrantadas- y la fruición por agotar la explotación de sus recursos, expresión emblemática del depósito de las normas del orden natural.

La solvencia de las consideraciones anteriores depende de la elocuencia vigorosa de su retransmisión a la opinión pública y del talante receptivo con que se les acoge. El ritmo y la insistencia de la mundialización llevan a denunciarlo, para que un sistema de medidas clarividentes y efectivas disuelva las actitudes de apatía, cuando no de animosidad, que se registran. Sirviendo a una consigna muy cara a los juristas, hace falta que el orden natural se ponga inmediatamente en pie de guerra. El ejemplo de un sistema constitucional que, como muestran los arts. 1.1 y 9.2 CE, rebasa, en homenaje a la justicia sustancial, las estrecheces éticas del normativismo, alecciona -irreprochable e implacablemente- al sanar de raíz las amnesias de las malas conciencias. Hay que trasladar ese convencimiento a la opinión pública y a la impregnación emocional que expande el espíritu del pueblo. Un reparto de cauces -que el estructuralismo asoció a otros caminos compatibles con 
las ofertas pacificadoras del legislador- se impone a medida que surgen y se multiplican los entorpecimientos de una aplicación judicial equitativa de las normas del ordenamiento jurídico.

Lo afirmado se relaciona con la oportunidad de subrayar la presencia y custodiar la integridad de ciertos derechos fundamentales. La libertad de empresa - a la que la sec. . $^{a}$, cap. $2 .^{\circ}$, tít. I CE no atribuye esa naturalezapasa a serlo sobrevenidamente, porque el principio de primacía del Derecho comunitario prohíbe adjudicarle una caracterización menos enérgica que la correspondiente a las libertades de establecimiento y circulación de capitales como derechos fundamentales de la UE. El tratamiento nacionalizado que las jurisdicciones estatales dedican a cuestiones conexas con el contenido esencial o núcleo invulnerable de estas libertades reduce la notabilidad de su enclave en el ordenamiento jurídico y desprestigia su eficacia. Se precisa que, ante tales anomalías, la equidad contribuya también a erradicar ese mal y algún otro de parecida gravedad.

La plenitud del sentimiento equitativo incluye, a todas luces, la utopía -tantas veces ansiada como vencida por los arrebatos de la sinrazón- de que el gobierno dialéctico o retórico del mundo prevalezca, pausada y victoriosamente, sobre las tensiones sociales de la fuerza. ¿De qué modo y manera? Levantando ciudades seculares cuyos planes refundan las afinidades y aptitudes de sus pobladores, reduzcan igualitariamente las privaciones de los grupos sociales afligidos por la discriminación y la pobreza, cumplan los compromisos de vivir en paz con todos y enseñen a creer en la esperanza. Así se racionaliza moralmente la vida política, en pro de cuya busca se exhortaba de antiguo a los cristianos a desprenderse de sus bienes y, si ello era preciso, a sacrificar sus propias vidas. Esa racionalización propende a que el conocimiento de las más íntimas exigencias humanas -especialmente de la fraternidad y de las energías subyacentes a la moralidad y la espiritualidad de la persona- forje un modelo de comportamiento secular que, a impulsos de la sensibilidad equitativa, proscriba el egoísmo, los celos desmedidos, el orgullo exaltado, la astucia sistemática, el ansia de dominación sobre los débiles y el hábito creciente de hacer de la mentira un modesto pecado venial.

\section{Bibliografía de orientación}

Barcellona, P. et al. L'uso alternativo del diritto. Roma-Bari: Ed. Laterza, 3 vols., 1974.

BeARDSley, S. et al. Human relations in international affairs: A Guide to significant interpretation and research. Washington: Ed. Public Affair Press, 1956.

BobBIo, N. «Sulla rinascita del Giusnaturalismo», Rivista di Filosofía, pp. 408-410. Padua: Ed. CEDAM, 1963. 
—Il positivismo giuridico. Turín: Ed. Giapichelli, 1979.

Boulding, K. Conflict and defence: A general theory. Nueva York: Ed. Harper, 1962.

BRIMO, A. Les grands courants de la philosophie du droit et de l'Etat. París:

Ed. A. Pedone, 1968.

CAHN, E. The sense of injustice. Nueva York: Ed. New York University Press, 1949.

CARbonnier, J. Derecho Civil, traducción y adiciones de conversión al Derecho español de Zorrilla, M. M., t. 1, v. 1. Barcelona: Ed. Bosch, 1960. CASTAN, J. «La formulación judicial del Derecho y el arbitrio de equidad», Revista General de Legislación y Jurisprudencia, pp. 219-272. Madrid: Ed. Reus, 1953.

DAVID, R. I grandi sistemi giuridici contemporanei. Padua: Ed. CEDAM, 1980.

CERroni, U. El pensamiento jurídico soviético, traducción de ZaPATERO, V. Madrid: Ed. EDICUSA, 1977.

De los Mozos, J. «La equidad en el Derecho Civil español», Revista General de Legislación y Jurisprudencia, pp. 326-365. Madrid: Ed. Reus, 1972.

DelhaYe, P. Permanence du droit naturel. Lovaina: Ed. Nauwelaerts, 1960.

Dessens, J. Essai sur la notion d'equité. Toulouse: tesis inédita, 1934.

GoldsMichDt, W. La Ciencia de la Justicia. Madrid: Ed. Aguilar, 1958.

Hernandez Gil, A. Métodología del Derecho. Madrid: Ed. Antonio Hernández Gil, 3 vols., 1971-1976.

Kelsen, H. Teoría general del Derecho y del Estado, traducción de García, E. Méjico: Ed. UNAM, 1988.

— ¿Qué es justicia?, traducción de Calsamiglia, A. Barcelona: Ed. Ariel, 1982.

KoschaKer, P. Europa y el Derecho Romano, traducción de SANTACRUZ, J. Madrid: Ed. Revista de Derecho Privado, 1955.

LECLERCQ, J. Du droit naturel a la sociologie. Lovaina: Ed. Spes, 1960.

LZ. Aranguren, J. L. Ética. Madrid: Ed. Biblioteca Nueva, 1997.

Maritain, J. L'homme et l'Etat. París: Ed. Du Cerf, 1965.

Messer, W. Deutsche Wertphilosophie der Gegenwart. Leipzig: Ed. Reinicke, 1926.

Pannick, D. Judges. Oxford-Nueva York: Ed. Oxford University Press, 1987.

PhILIPS, H. A first book of English law. Londres: Ed. Sweet \& Maxwell, 1965.

PoulantZas, N. Nature des choses et droit. París: Ed. Librairie Generale de Droit et de la Jurisprudence, 1966.

RodríGuez IgLESIAs, G.C. et al. El Derecho Comunitario Europeo y su aplicación judicial. Madrid: Ed. Civitas, 1993. 
Rousseau C. Derecho Internacional Público, trad. de GZ. Artigues, F. Barcelona: Ed. Ariel, 1957.

Ruiz Moreno, M. Filosofía del Derecho: Teoría general e historia de doctrinas. Buenos Aires: Ed. Guillermo Kraft, 1944.

SosA, F. Los juristas de la 2. ${ }^{a}$ República. Madrid: Ed. Fundación «Alfonso Martínez Escudero» y Marcial Pons, 2009.

STERN, J. La codificación: Una controversia programática basada en las obras de ThIBAUT y SAVIGNY, traducción de DíAZ, J. Madrid: Ed. Aguilar, 1970.

Torralba, V. «Artículo 3.2 del Código Civil», Comentarios a las reformas del Código Civil, v.1, pp. 165-194. Madrid: Ed. Tecnos, 1977.

VIEHWEG, T. Tópica y jurisprudencia, traducción de DíAZ PICAZO, L. y prólogo de García De Enterría, E. Madrid: Ed. Taurus, 1964.

ZorRILla, M. M. «Modernidad y moralidad de la mundialización», Estudios de Deusto, vol. 50/2, 2002, pp. 181-196.

- «Del sometimiento al imperio de la ley, a la modernidad del arbitraje», Estudios de Deusto, vol. 55/2, 2007, pp. 185-211.

— «Aportaciones especiales de Derecho y equidad en las vicisitudes del concurso», Estudios de Deusto, vol. 56/2, 2008, pp. 165-187.

— «Preferencias y oportunidades moralizadoras en la aplicación judicial del Derecho», La relación del juez con la ley, pp. 137-167. Madrid: Ed. Consejo General del Poder Judicial, 2009. 